\title{
Developmental exposure to DDT or DDE alters sympathetic innervation of brown adipose in adult female mice
}

Annalise N. vonderEmbse ${ }^{1,2}$, Sarah E. Elmore ${ }^{1,3}$, Kyle B. Jackson ${ }^{1,4}$, Beth A. Habecker ${ }^{5}$, Katherine E. Manz ${ }^{6}$, Kurt D. Pennell ${ }^{6}$, Pamela J. Lein ${ }^{2}$ and Michele A. La Merrill ${ }^{1 *}$ (i)

\begin{abstract}
Background: Exposure to the bioaccumulative pesticide dichlorodiphenyltrichloroethane (DDT) and its metabolite dichlorodiphenyldichloroethylene (DDE) has been associated with increased risk of insulin resistance and obesity in humans and experimental animals. These effects appear to be mediated by reduced brown adipose tissue (BAT) thermogenesis, which is regulated by the sympathetic nervous system. Although the neurotoxicity of DDT is wellestablished, whether DDT alters sympathetic innervation of BAT is unknown. We hypothesized that perinatal exposure to DDT or DDE promotes thermogenic dysfunction by interfering with sympathetic regulation of BAT thermogenesis.
\end{abstract}

Methods: Pregnant C57BL/6 J mice were administered environmentally relevant concentrations of DDTs ( $p, p^{\prime}-$ DDT and o, $p^{\prime}-\mathrm{DDT}$ ) or DDE (p, $\left.\mathrm{p}^{\prime}-\mathrm{DDE}\right), 1.7 \mathrm{mg} / \mathrm{kg}$ and $1.31 \mathrm{mg} / \mathrm{kg}$, respectively, from gestational day 11.5 to postnatal day 5 by oral gavage, and longitudinal body temperature was recorded in male and female offspring. At 4 months of age, metabolic parameters were measured in female offspring via indirect calorimetry with or without the $\beta 3$ adrenergic receptor agonist, $\mathrm{CL}$ 316,243. Immunohistochemical and neurochemical analyses of sympathetic neurons innervating BAT were evaluated.

Results: We observed persistent thermogenic impairment in adult female, but not male, mice perinatally exposed to DDTs or p,p'-DDE. Perinatal DDTs exposure significantly impaired metabolism in adult female mice, an effect rescued by treatment with $C L 316,243$ immediately prior to calorimetry experiments. Neither DDTs nor p, $p^{\prime}-\mathrm{DDE}$ significantly altered BAT morphology or the concentrations of norepinephrine and its metabolite DHPG in the BAT of DDTs-exposed mice. However, quantitative immunohistochemistry revealed a $20 \%$ decrease in sympathetic axons innervating BAT in adult female mice perinatally exposed to DDTs, but not p,p'-DDE, and 48 and $43 \%$ fewer synapses in stellate ganglia of mice exposed to either DDTs or $p, p^{\prime}-D D E$, respectively, compared to control.

Conclusions: These data demonstrate that perinatal exposure to DDTs or p, $p^{\prime}$-DDE impairs thermogenesis by interfering with patterns of connectivity in sympathetic circuits that regulate BAT.

Keywords: Brown adipose tissue, P,p'-DDE, DDT, Obesogen, Sympathetic innervation, Synaptic connectivity, Thermogenesis, Perinatal exposure

\footnotetext{
* Correspondence: mlamerrill@ucdavis.edu

${ }^{1}$ Department of Environmental Toxicology, University of California-Davis

College of Agricultural and Environmental Sciences, One Shields Avenue,

Davis, CA 95616, USA

Full list of author information is available at the end of the article
}

C C The Author(s). 2021 Open Access This article is licensed under a Creative Commons Attribution 4.0 International License, which permits use, sharing, adaptation, distribution and reproduction in any medium or format, as long as you give appropriate credit to the original author(s) and the source, provide a link to the Creative Commons licence, and indicate if changes were made. The images or other third party material in this article are included in the article's Creative Commons licence, unless indicated otherwise in a credit line to the material. If material is not included in the article's Creative Commons licence and your intended use is not permitted by statutory regulation or exceeds the permitted use, you will need to obtain permission directly from the copyright holder. To view a copy of this licence, visit http://creativecommons.org/licenses/by/4.0/ The Creative Commons Public Domain Dedication waiver (http://creativecommons.org/publicdomain/zero/1.0/) applies to the data made available in this article, unless otherwise stated in a credit line to the data. 


\section{Background}

Exposure to the pesticide dichlorodiphenyltrichloroethane (DDT), and its primary metabolite dichlorodiphenyldichloroethylene (DDE), remains a significant public health concern because it is persistent and bioaccumulative and has a long history of widespread global use. Further, exposure is ongoing in many parts of the world because of the recommended use of DDT for malaria control by the World Health Organization, due in part to widespread anti-malarial drug resistance [1]. For example, the median levels of DDT and DDE detected in the blood of immigrants to the USA from India, where DDT continues to be manufactured, exceeded the 95th percentile of DDT and DDE levels in the general U.S. population, and was significantly associated with their increased body mass index and increased odds of obesity in a 2019 study [2].

Exposures to environmental chemicals known as obesogens may play a significant role in the multifactorial etiopathology of obesity, which has become a worldwide epidemic [3-5]. Recent systematic reviews and metaanalyses have concluded that developmental exposure to DDT and DDE is consistently associated with higher body mass index and other measures of adiposity in humans, rats, and mice $[2,6,7]$. For example, perinatal administration of a technical mixture of DDTs (p,p'DDT and o,p'-DDT) at levels that resulted in humanrelevant serum levels of DDTs and p,p'-DDE was associated with reduced energy expenditure and body temperature and increased body fat in adult female mice [8]. Decreased energy expenditure and body temperature are strongly associated with increased susceptibility for obesity [9-13].

Subsequent mechanistic studies of the metabolic effects resulting from perinatal exposure to the technical mixture of DDTs revealed decreased thermogenic signaling in brown adipose tissue (BAT) of 9 month old female mice. The activity of BAT in adult humans is inversely correlated with obesity, diabetes, and insulin resistance [14], and BAT transplantation has been shown to reverse obesity in rodents [15]. Adaptive thermogenesis by BAT is regulated by the sympathetic nervous system (SNS) via norepinephrine (NE) signaling, which stimulates brown adipocytes to generate heat by uncoupling mitochondrial oxidative phosphorylation with an uncoupling protein 1 (UCP1)- mediated proton leak [16]. While the role of adipose dysfunction has been well characterized in studies of DDT and DDE influence on obesity and metabolic disease [17-19], the potential role of DDTs and p,p'-DDE neurotoxicity in initiating or exacerbating these disorders is less clear. The insecticidal activity of DDT is attributed to its interaction with voltage-gated sodium channels to stabilize the channels in their open configuration, resulting in repetitive neuronal firing and hyperexcitability [20]. In addition to this canonical mechanism of neurotoxicity, DDT has been reported to alter in vivo levels of neurotransmitters, including norepinephrine [21], and to inhibit neurite outgrowth in vitro [22, 23]. The potential relevance of these latter observations to the mechanisms by which DDT alters thermogenesis is suggested by rodent studies in which sympathetic denervation of BAT was observed to significantly impair thermogenesis and energy balance coincident with increased body mass [24-29]. But whether developmental administration of DDTs or p,p'-DDE alters the peripheral sympathetic nervous system has not been investigated.

To address this knowledge gap, we leveraged a previously characterized mouse model of developmental exposure to DDTs that caused thermogenic impairment [8], and extended it to include developmental p,p'-DDE exposure. Mice were exposed developmentally to a commercially relevant mixture of p,p'-DDT and o,p'$\mathrm{DDT}$, or to the in vivo persistent metabolite p,p'-DDE. In addition to measuring various thermogenesis parameters, we quantified synaptic connectivity between preand postganglionic sympathetic neurons of the stellate ganglia and between postganglionic sympathetic neurons and BAT. Our data support the hypothesis that DDTs and p,p'-DDE cause persistent defects in adaptive thermogenesis by altering synaptic connectivity of sympathetic neurons that innervate BAT.

\section{Methods}

\section{Chemicals}

The aim of the present study was to determine whether developmental DDT exposures that impair thermogenesis later in life alter sympathetic innervation of BAT. To mimic the typical commercial formulation of DDT prior to its ban in the United States, the DDTs used to dose animals was a combination of $77.2 \%$ p,p'-DDT (98.5\% purity neat, AccuStandard, New Haven, CT, USA) and $22.8 \%$ o,p'-DDT (100\% purity neat, AccuStandard). For the DDE exposure, only p,p'-DDE (100\% purity neat, AccuStandard) was used. Both p,p'-DDE and the DDTs mixture were separately dissolved in the vehicle (Veh), organic extra virgin olive oil from Italian grown olives (Nugget Markets, Woodland, CA, USA), at a concentration of $1.7 \mathrm{mg} / \mathrm{kg}$ (DDTs) and $1.31 \mathrm{mg} / \mathrm{kg}$ (p, p'-DDE), which was administered daily by oral gavage ( $10 \mu \mathrm{L} / \mathrm{kg}$ body weight per day). Dosing solutions were prepared at the beginning of the experiment, stored at room temperature (RT, $21-23^{\circ} \mathrm{C}$ ) in a gas-tight container, and used within two months. For indirect calorimetry experiments, the $\beta 3$ adrenergic receptor (AR) agonist CL316,243 (CAS No: 151126-84-0, Cat \#1499, 98.1\% purity neat; TOCRIS) was dissolved daily in sterile phosphate-buffered saline (PBS, pH 7.4; cat\#59321C, 
Sigma, St. Louis, MO, USA) at a concentration of 0.1 $\mathrm{mg} / \mathrm{mL}$ and warmed to $37^{\circ} \mathrm{C}$ prior to intraperitoneal (i.p.) injection at a volume of $10 \mu \mathrm{L} / \mathrm{g}$ body weight.

Certified reference standards for HPLC quantification were purchased from Accustandard, including o,p' DDT, p,p'-DDT, o,p'-DDE, p,p'-DDE, ${ }^{13} \mathrm{C}_{12}$ labeled p,p'-DDE, $\mathrm{D}_{8}$ labeled p,p'-DDT, phenanthrene D-10, and chrysene D-12. Acetone (99.8\%, HPLC grade), n-hexane ( $\geq 99 \%)$, and dichloromethane (99.8\%, HPLC grade) were purchased from Fisher Scientific.

\section{Animal handling and exposures}

Animals were maintained in facilities fully accredited by AAALAC International, and all studies were performed with regard for alleviation of pain and suffering under protocols approved by the UC Davis Institutional Animal Care and Use Committee (IACUC protocol \#18938). All animal experiments were conducted in accordance with the ARRIVE guidelines and the National Institutes of Health guide for the care and use of laboratory animals (NIH publication No. 8023, revised 1978). Male and female 8-week-old C57BL/6 J mice were obtained from Jackson Laboratories (Sacramento, CA, USA). Except during mating, adult male and female mice were separately housed with 2-5 animals per cage in standard plastic cages under controlled environmental conditions (12 h light/dark cycle, 40-50\% humidity). Litters were kept with the dam until weaned at postnatal day (PND) 21. Room temperature was maintained between 21 and $23^{\circ} \mathrm{C}$, which is considered a minor cold stress with the potential for stimulating low-grade sympathetic activation [30, 31], to mimic thermoregulatory conditions for equivalent metabolic activity in humans [32]. All animals had access to food (5053 Purina diet) and water $a b$ libitum. Upon receipt from the vendor (Jackson Laboratories), 8-week-old male and nulliparous female C57BL/6 J mice were acclimated for one week prior to timed mating. Pregnancy was determined by the presence of a postcoital vaginal plug. Primigravid females were randomly assigned to experimental groups using a random number generator, using a priori decisions to maximize litter number per group based on sex per litter; thus, final counts for sex-based longitudinal rectal temperature were $n=14$ (Veh), 15 (DDTs) or 7 (p,p'-DDE) non-littermates/group for a total of 36 litters, and all remaining analyses in females at $n=7$ nonlittermates/group for a total of 21 litters, unless otherwise stated in the figure or table legends. Once assigned to an experimental group, dams were orally gavaged $(10 \mu \mathrm{L} / \mathrm{g}$ body weight) with DDTs (p,p'-DDT and o, p'DDT), DDE (p,p'-DDE), or Veh from gestational day (GD) 11.5 until postnatal day (PND) 5. This period encompasses crucial ontological events for autonomic ganglionic formation, establishment of peripheral sympathetic synaptic connections, sympathetic target tissue innervation, and BAT activation by the sympathetic nervous system [16, 33, 34]. At PND 5, litters were culled to 6 random pups to normalize lactational pesticide transfer, and pups were weaned at PND 21. At 4 months of age, female offspring were euthanized by exsanguination under isoflurane anesthesia. The experimental design is represented schematically in Fig. 1a.

\section{Temperature measurements and indirect calorimetry}

Longitudinal core body temperature was measured in female offspring in four-week intervals beginning at 5 weeks after birth using a thermocoupled probe (RET-4, Physitemp, Clifton, NJ, USA) inserted into the rectum to a depth of $5 \mathrm{~mm}$.

Thermoneutral zone (TNZ) was assessed using indirect calorimetry with implanted temperature recorders. DST nano-T temperature recorders (Star-Oddi, Gardabaer, Iceland) were implanted intraperitoneally under anesthesia (2-4\% isoflurane). For analgesia, animals received meloxicam $(2-10 \mathrm{mg} / \mathrm{kg}$, subcutaneous, SC) pre-operatively and, as needed, buprenorphine (0.05-0.1 $\mathrm{mg} / \mathrm{kg}, \mathrm{SC}$ ) post-operatively. Mice were moved to the calorimetry room at least ten days after surgery. Mice were acclimated to the calorimetry room for $24 \mathrm{~h}$ while housed in acclimation chambers. The morning of TNZ analysis, food was removed from the acclimation chamber to ensure that calorimetry readings were not influenced by foraging activity. To evaluate the TNZ, a mouse in an acclimation chamber was transferred to a calorimetry chamber within a temperature-controlled cabinet set at $12{ }^{\circ} \mathrm{C}$. Cage temperature was measured using ambient temperature sensors (DS1922L-F5\#, iButtonLink, LLC) attached to the inside of the metabolic cage lid. Previous tests measuring temperature within the calorimeter chambers were used to select the chamber location for the studies that best matched the target temperatures. Energy expenditure was determined by indirect respiration calorimetry [35] recorded every $5 \mathrm{~s}$ in the Comprehensive Lab Animal Monitoring Systems (CLAMS, Columbus Instruments) unit at $12^{\circ} \mathrm{C}$ for 60 min, at $18{ }^{\circ} \mathrm{C}, 24^{\circ} \mathrm{C}, 28^{\circ} \mathrm{C}$, and $30^{\circ} \mathrm{C}$ for $45 \mathrm{~min}$ each, and at $34^{\circ} \mathrm{C}$ and $36^{\circ} \mathrm{C}$ for $30 \mathrm{~min}$ each. The body temperature recorders were programmed to record every $5 \mathrm{~min}$ from the beginning of the $12^{\circ} \mathrm{C}$ interval until the beginning of the $30{ }^{\circ} \mathrm{C}$ calorimetry measurements and for every minute for the remainder of the calorimetry measurements $\left(30^{\circ} \mathrm{C}\right.$ through $\left.36^{\circ} \mathrm{C}\right)$.

Oxygen consumption and heat production in response to CL316,243 was determined by indirect calorimetry [35]. Four-month old female mice were individually housed in CLAMS metabolic chambers and acclimated for at least three days prior to data acquisition. Due to an insufficient number of CLAMS cages for simultaneous, age-dependent 
analysis of the three exposure groups, indirect calorimetry was performed only on the mice exposed to DDTs or Veh. On the day of pharmaceutical intervention, mice had food and water removed for $4 \mathrm{~h}$ prior to intraperitoneal injection (IP) injection with either CL316,243 $(0.1 \mathrm{mg} / \mathrm{kg})$ or Veh (sterile phosphate buffered saline [PBS], pH 7.4; \#59321C, SigmaAldrich, St. Louis, Missouri, USA) by researchers blinded to experimental groups. Subsequent indirect calorimetry metrics were recorded for the next 60 min, with sampling frequency at one min intervals. Measurements were averaged over a 20 min window after chamber gas equilibration, from post-injection minute 11 to 31 to encompass a period of peak BAT activation by CL316,243 [36]. Room temperature was maintained between 21 and $23^{\circ} \mathrm{C}$, rather than at TNZ due to the lack of a DDTs-related shift of TNZ (Supplemental Table 1) and kept on a $12 \mathrm{~h}$ light/dark cycle.

\section{Histology and immunofluorescence}

BAT was collected from the intrascapular region immediately following euthanasia. BAT was fixed in $4 \%$ $(\mathrm{w} / \mathrm{v})$ paraformaldehyde (PFA; Sigma) diluted in $0.2 \mathrm{M}$ phosphate buffer $\left(0.2 \mathrm{M} \mathrm{Na}_{2} \mathrm{HPO}_{4}, 0.2 \mathrm{M} \mathrm{NaH} \mathrm{NO}_{4}\right.$, $\mathrm{pH} 7.2)$ for $24 \mathrm{~h}$, then transferred to $30 \%(\mathrm{w} / \mathrm{v})$ sucrose (Sigma) diluted in phosphate buffered saline

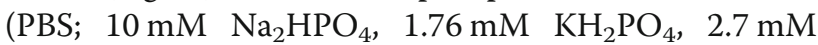
$\mathrm{KCl}, 137 \mathrm{mM} \mathrm{NaCl}$; pH 7.4; Sigma) for long-term storage at $4{ }^{\circ} \mathrm{C}$. Fixed BAT samples were transferred into $70 \% \mathrm{v} / \mathrm{v}$ ethanol in water, then embedded in paraffin. Three $5 \mu \mathrm{m}$ thick sections were obtained at $100 \mu \mathrm{m}$ intervals per tissue sample and stained with hematoxylin and eosin (H\&E). H\&E-stained sections were analyzed by the UC Davis Comparative Pathology Laboratory (UC Davis School of Veterinary Medicine). A pathologist blinded to study groups examined BAT sections for inflammation, degeneration and necrosis. Vacuolation of BAT adipocytes was subjectively classified as the ratio of cells with small to large intracytoplasmic vacuoles. This quantification avoided obvious tissue edge and blood vessels, and assumed unstained round cellular droplets to be lipids contained within intracytoplasmic vacuoles.

For immunohistochemical analyses, PFA-fixed BAT was embedded in optimal cutting temperature (OCT) compound (\#4583, Tissue-Tek, Sakura Finetek, Torrance, CA, USA) and flash-frozen. Three sections per sample were serially sliced $10 \mu \mathrm{m}$ thick mounted on Superfrost Plus slides (Cat\#12-550-15, Fisher Scientific) using a cryostat set to $-30{ }^{\circ} \mathrm{C}$ (Microm HM550 cryostat, Thermo Scientific), and slides were stored at $-80^{\circ} \mathrm{C}$ until further processed. Once slides were brought to room temperature (RT), heatmediated antigen retrieval was performed on slides submerged in citrate buffer $(10 \mathrm{mM}$ sodium citrate in $0.05 \%(\mathrm{v} / \mathrm{v})$ Tween-20 [Sigma-Aldrich] diluted with MilliQ $\mathrm{H}_{2} \mathrm{O}, \mathrm{pH}$ 6.0) using a vegetable steamer for 30 min to attain a minimum temperature of $60{ }^{\circ} \mathrm{C}$. Following antigen retrieval, samples were blocked for $1 \mathrm{~h}$ at RT in blocking buffer, which was $10 \%(\mathrm{v} / \mathrm{v})$ normal goat serum (Vector Laboratories, Burlingame, CA, USA), 2\% (w/v) bovine serum albumin (Sigma), 0.05\% (v/v) Tween-20 in PBS (pH 7.4, Sigma). Sections were then immunoreacted for $48 \mathrm{~h}$ at $4{ }^{\circ} \mathrm{C}$ with the following primary antibody cocktail diluted in blocking buffer: mouse anti-neuropeptide Y (NPY) (1:250, monoclonal IgG1, ab112473, RRID:AB_10861167; Abcam, Cambridge, MA, USA) and rabbit antityrosine hydroxylase (TH) (1:1000, polyclonal, Cat \#AB152, RRID: AB_390204; EMD Millipore, Temecula, CA, USA). After incubation with primary antibodies, sections were washed with PBS containing $0.05 \%(\mathrm{v} / \mathrm{v})$ Tween-20 and then incubated for $1 \mathrm{~h}$ at RT with AlexaFluor-488 goat anti-mouse IgG F(ab')2 (lot\#1812170, Invitrogen, Waltham, MA, USA) and AlexaFluor-568 goat anti-rabbit IgG (lot\#1871167, Invitrogen) each diluted to $1: 1000$ in PBS (pH 7.4) containing $0.05 \%(\mathrm{v} / \mathrm{v})$ Tween-20. Sections were then washed and coverslipped with ProLong Gold Antifade Mountant with 4',6-diamidino-2-phenylindole, (DAPI, P36931, ThermoScientific) and left to cure overnight before imaging.

To immunostain stellate ganglia, unfixed stellate ganglia collected immediately upon euthanasia were immediately embedded in OCT (Tissue-Tek) and flash frozen. Samples were serially cryosectioned at $10 \mu \mathrm{m}$, permeabilized for 5 $\min$ in $0.2 \%(\mathrm{v} / \mathrm{v})$ Triton X-100, and then blocked for $2 \mathrm{~h}$ at RT with blocking buffer. Slides were then immunoreacted overnight at $4{ }^{\circ} \mathrm{C}$ with primary antibody cocktail diluted in blocking buffer: rabbit anti-chapsyn-100 (PSD93) (1:500, polyclonal, AB5168-200UL, RRID:AB_91716; EMD Millipore) and mouse anti-bassoon (1:500, ADI-VAMPS003-F, RRID:AB_11181058; ENZO Life Sciences, Plymouth Meeting, PA, USA). After incubation with primary antibodies, sections were washed with PBS containing $0.02 \%(\mathrm{v} / \mathrm{v})$ Tween-20 and then incubated for $1 \mathrm{~h}$ at RT with AlexaFluor-488 goat anti-mouse IgG F(ab')2 (lot\#1812170, Invitrogen) and AlexaFluor-568 goat antirabbit IgG (lot\#1871167, Invitrogen) each diluted to 1 : 1000 in PBS with $0.02 \%(\mathrm{v} / \mathrm{v})$ Tween-20. Sections were then washed and coverslipped with ProLong Gold Antifade Mountant with DAPI (P36931, Thermo Scientific) and left to cure overnight before imaging. Staining batches were evenly stratified across all treatment groups to minimize batch effects, and appropriate controls were included in each stain batch for downstream interbatch comparisons and thresholding determinations to optimize signal:noise during quantification. 


\section{Catecholamine concentrations}

BAT ( $n=7$ /group) was collected immediately after euthanasia and flash frozen. Tissue was homogenized in perchloric acid $(300 \mu \mathrm{l}, \quad 0.1 \mathrm{M})$ containing dihydroxybenzylamine $(1.0 \mu \mathrm{M})$ internal standard. After homogenization, all samples were centrifuged $(13,000 \mathrm{~g}$ for $5 \mathrm{~min})$. Catecholamines were purified from an aliquot $(100 \mu \mathrm{L})$ of the supernatant by alumina adsorption. Norepinephrine (NE) and its metabolite dihydroxyphenylglycol (DHPG) were measured by HPLC with electrochemical detection as described previously [37-39]. Detection limits were $\sim 0.05$ pmol with recoveries from the alumina extraction $>60 \%$.

\section{DDT and DDE concentration quantification}

Tissue concentrations of o,p'-DDT, p,p'-DDT, o,p'-DDE, and p,p'-DDE were measured in BAT from 4-month-old mice using gas chromatography (GC)-MS following methods described previously [2]. Briefly, $30 \mathrm{mg}$ flash frozen BAT samples ( $n=3$ /group) were extracted using a QuEChERS-based extraction with 1:1:1 hexane:acetone:dichloromethane. Briefly, the samples were spiked with $10 \mu \mathrm{L}$ of a solution containing ${ }^{13} \mathrm{C}_{12}$ labeled p,p'DDE and $\mathrm{D}_{8}$ labeled p,p'-DDT as internal standards to assess recovery. The samples and $5 \mathrm{~mL}$ of the solvent mixture were added to 7-dram amber vials and vortexed mixed. The supernatant was added to a $15 \mathrm{~mL}$ QuEChERS tube containing $150 \mathrm{mg}$ dispersive $\mathrm{C} 18$ powder and $900 \mathrm{mg}$ anhydrous $\mathrm{MgSO}_{4}$ (United Chemical Technologies, Bristol, PA). The Quechers tube was shaken for $15 \mathrm{~min}$ on a rotary shaker (Fisherbrand) and centrifuged $(5 \mathrm{~min})$. The supernatant was transfer to a glass centrifuge tube. These steps were repeated two more times with $3 \mathrm{~mL}$ of 1:1:1 hexane:acetone:dichloromethane $(11 \mathrm{~mL}$ total). The final extract was evaporated down to $150 \mu \mathrm{L}$ under nitrogen (Organomation 30 position Multivap Nitrogen Evaporator). After extraction, samples were spiked with phenanthrene-D10 and chrysene D-12 as internal standards to ensure injection consistency during GC-MS analysis.

Sample extracts were then analyzed on a high-resolution GC Q-Exactive Orbitrap MS (Thermo Scientific) equipped with a Thermo Trace 1300 gas chromatograph and TriPlus RSH Autosampler. The extracts $(3 \mu \mathrm{L})$ were injected into a $290^{\circ} \mathrm{C}$ split/splitless inlet operated in split-less mode. The analytes were separated on a Restek Rxi-35Sil MS column $(30 \mathrm{~m} \times 0.25 \mathrm{~mm}$ inner diameter $\times 0.25 \mu \mathrm{m}$ film thickness) with Helium (99.999\% purity) as the carrier gas $(1 \mathrm{~mL} /$ min). The oven temperature ramp began at $130^{\circ} \mathrm{C}$ for 0.5 min, increased $30^{\circ} \mathrm{C} / \mathrm{min}$ to $235^{\circ} \mathrm{C}$ and held for $4 \mathrm{~min}$, $10^{\circ} \mathrm{C} / \mathrm{min}$ to $275^{\circ} \mathrm{C}$, and $50^{\circ} \mathrm{C} / \mathrm{min}$ to $320^{\circ} \mathrm{C}$ and held for $10 \mathrm{~min}$, with a total run time of $23 \mathrm{~min}$. The transfer line was maintained at $300^{\circ} \mathrm{C}$ and the EI source temperature at $250^{\circ} \mathrm{C}$. The MS was operated in full scan mode, with a scan range of 150 to $350 \mathrm{~m} / \mathrm{z}$. The most abundant peak in the mass spectrum was used to quantify each analyte and identify was confirmed using the ratio of two confirming ions and retention times (Table 1). Quantification was performed using a ten-point calibration curve prepared by serial dilution of calibration standards in hexane $(.007$ to $30 \mu \mathrm{g} \mathrm{L}{ }^{-1}$ ). The limited of detection (LOD) for each target analyte was determined from seven injections of calibration standards and calculated as previously described [40, 41] using the following equation:

$$
L O D=s * t(d f, 1-\alpha=0.99)
$$

where $\mathrm{s}$ is the standard deviation of the 7 injections, $\mathrm{t}$ is the student's t-value, $\mathrm{df}$ is the degrees freedom, and $\alpha$ is the level of significance (for $n=7$ and $\alpha=0.01, t=3.14$ ). Limits of detection (LOD) per metabolite in a $30 \mathrm{mg}$ BAT sample were as follows: $0.026 \mathrm{pg} / \mathrm{mg}$ BAT (p,p'DDT), $0.269 \mathrm{pg} / \mathrm{mg}$ BAT (p,p'-DDE), $0.153 \mathrm{pg} / \mathrm{mg}$ BAT (o,p'-DDT), and $0.104 \mathrm{pg} / \mathrm{mg}$ BAT (o,p'-DDE).

\section{Data processing and analyses}

The lower critical temperature (LCT) of the TNZ, previously reported to be between 26 and $32{ }^{\circ} \mathrm{C}$ for varying strains of laboratory mice [32, 42], was calculated using a segmental linear model of energy expenditure versus calorimeter chamber temperature with the slope $2=0$. Although the upper critical temperature (UCT) of the TNZ is frequently defined as the ambient temperature where heat stress induces an increase in energy

Table 1 Retention time and ions monitored to quantify and confirm DDE metabolites

\begin{tabular}{|c|c|c|c|c|}
\hline Analyte & RT (min) & $\begin{array}{l}\text { Quantifying lon } \\
(\mathrm{m} / \mathrm{z})\end{array}$ & $\begin{array}{l}\text { Confirming lon } 1 \\
(\mathrm{~m} / \mathrm{z})\end{array}$ & $\begin{array}{l}\text { Confirming lon } 2 \\
(\mathrm{~m} / \mathrm{z})\end{array}$ \\
\hline $0, p^{\prime}-D D E$ & 8.36 & 245.9999 & 247.9968 & 317.9345 \\
\hline o,p'-DDT & 10.64 & 235.0076 & 165.0699 & 237.0047 \\
\hline$p, p^{\prime}-D D E$ & 9.10 & 245.9999 & 247.9968 & 317.9345 \\
\hline$p, p^{\prime}-D D T$ & 11.35 & 235.0076 & 165.0699 & 237.0047 \\
\hline $4,4^{\prime}-\mathrm{DDE}\left({ }^{13} \mathrm{C}_{12}\right)$ & 9.17 & 260.0370 & 188.1021 & 258.0400 \\
\hline 4,4'-DDT $\left(\mathrm{D}_{8}\right)$ & 11.27 & 243.0576 & 173.1200 & 245.0549 \\
\hline
\end{tabular}

$R T$ retention time 
expenditure [43], we did not consistently observe increases in energy expenditure even at ambient temperatures where body temperature was increased (See Supplementary Table 1, Additional file 1). Therefore, we followed the approach suggested by Abreu-Vieira et al. [44] and used an increase in body temperature to identify the UCT. The UCT was calculated using a segmental linear model of core body temperature versus calorimetry chamber temperature with the slope $1=0$. Energy expenditure in mice was measured at temperatures ranging from 12 to $36^{\circ} \mathrm{C}$, after which Scholander plots were constructed [45] to determine the effect of ambient temperature on energy expenditure and identify the TNZ (Table S1). Only body temperature data collected at calorimetry chamber temperatures above $28^{\circ} \mathrm{C}$ were used for the calculations to avoid fluctuations in body temperature that were more common at colder temperatures.

Images of immunofluorescence were captured using an Olympus IX81 wide-field microscope with either a 20x SAPO BF or 60x SAPO BF objective lens for BAT and stellate, respectively, with consistent exposure times across all samples. Regions of interest (ROIs) were randomly selected per tissue section $(n=1-3$ ROI technical replicates within each section, depending on the availability of non-overlapping viewing fields and tissue size) for each of the three tissue sections per slide, for a total of $n=3-9$ ROIs per sample evaluated. Automated, nonbiased colocalization analyses were performed using MetaXpress Image Analysis Software (MetaXpress Image Acquisition and Analysis Software v6.1, Molecular Devices Corp., USA) based on a priori-designated signal: noise ratios per channel and background fluorescence thresholds for tissue-specific immunopositive staining. Target-specific controls lacking primary or secondary antibodies were included in each staining batch to determine thresholds for immunopositive fluorescence and adjust for batch effects.

All data were presented as the mean \pm standard error of the mean (SE). Data were assessed for normality using Kolmogorov-Smirnov or Shapiro-Wilk normality tests, and outliers were removed based on identification via Grubb's test (GraphPad Prism version 8.4.0, GraphPad Software Inc., San Diego, CA, USA). Histological analyses and catecholamine measurements were then assessed using either nonparametric Kruskal-Wallis tests with Dunn's correction for data not normally distributed (e.g. H\&E histology data) or analysis of variance (ANOVA) with Tukey's correction for normally distributed data (e.g. immunofluorescence and catecholamine outcomes) using GraphPad PRISM 7. Body temperature was normally distributed and thus least square means differences between categorical effect of perinatal treatment were analyzed at each age using general linear models (PROC GLM, SAS v9.4, Statistical Analysis System (SAS) Institute, Cary, NC, USA). Indirect calorimetry-derived parameters were modeled with the fixed effects of perinatal exposure, acute (agonist or Veh) exposure, and their interaction, while accounting for the repeated measures from individual mice and resulting covariance structure in a mixed linear model that allows the data to exhibit within- individual correlation (PROC MIXED, SAS v9.4). All parameters were statistically analyzed at a significance threshold of $p<0.05$ for main effects and $p<0.1$ for interaction effects.

\section{Results}

It was previously reported that perinatal exposure to a mixture of DDTs caused significant defects in thermogenesis in adult female mice that increased in severity with age [8]. To confirm and further extend these earlier findings, we examined the effects on thermogenesis of perinatal exposure to not only DDTs (which results in a mixed exposure to DDT and DDE due to metabolism of DDTs), but also to p,p'-DDE only in adult male and female mice. We found toxicant-related thermogenic impairment that manifested in adulthood among female mice exposed to either DDTs or p,p'-DDE (Fig. 1). Specifically, while no significant toxicant-related differences in body temperature were present in either sex at 5 weeks of age, by 11 weeks exposure to either DDTs or $\mathrm{p}$, p'-DDE significantly reduced female body temperature compared to Veh controls (Fig. 1b, Supplemental Table 2). The female-specific temperature defect persisted out to 15 weeks in both the DDTs and p,p'-DDE exposure groups (Fig. 1b, Supplemental Table 2). In contrast, body temperature of male offspring was unaltered by early-life exposure to DDTs or p,p'-DDE up to 15 weeks of age (Fig. 1c, Supplemental Table 2), confirming the previously reported sex bias in DDTs-induced thermogenic impairment [8].

Reduced thermogenesis could be further revealed by increased vacuolization of multilocular brown adipocytes, which are reminiscent of adipocytes with lowered thermogenic capacity [46-48]. To determine whether perinatal DDTs or p,p'-DDE exposure altered vacuolization of brown adipocytes, H\&E histochemical staining of adult BAT was performed. The ratio of small to large lipid vacuoles, a quantitative metric of brown adipocyte multilocularity $[47,48]$, was unaffected by either DDTs or p,p'-DDE (Fig. 2b), indicating no abnormal lipid storage or "whitening" of brown adipocytes that may have contributed to the overall metabolic phenotype at this age. Indeed, no changes to BAT morphology as a result of perinatal DDTs- or p,p'-DDE- exposure were apparent by light microscopy (Fig. 2a). 
A.

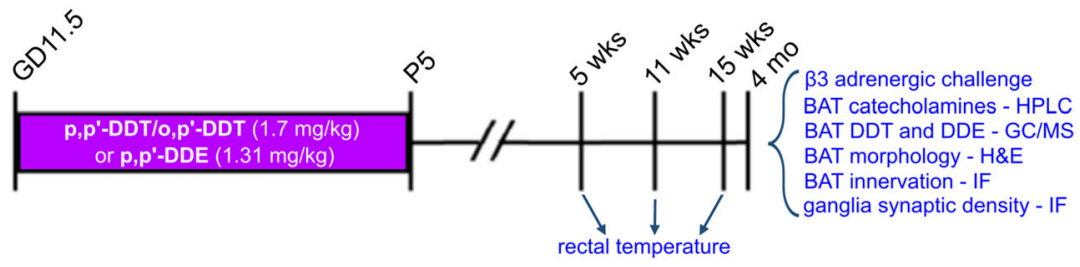

B.

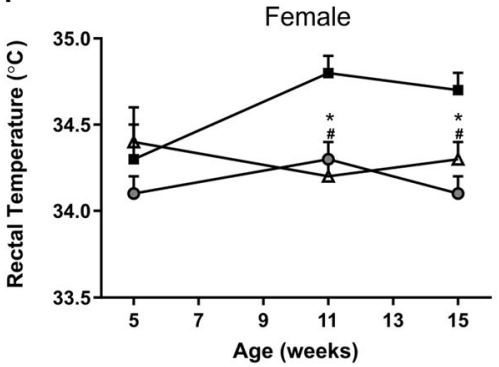

C.

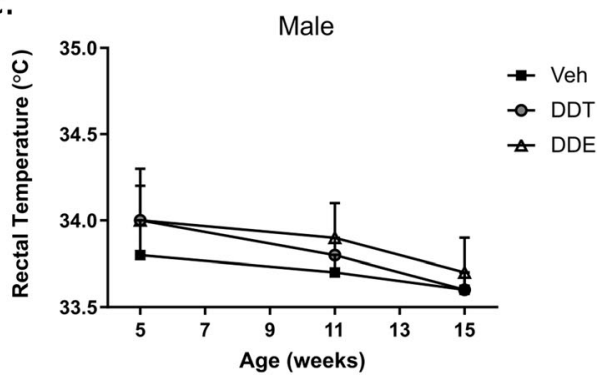

Fig. 1 Reduced core body temperature in female mice exposed during early development to DDTs or p,p'-DDE. a Schematic diagram of experimental design, including timing of exposure from GD11.5 to P5, and age-specific measurement and analyses in blue. b, c Core body temperature measured at 5, 11, and 15 weeks in female (b) and male (c) offspring to assess impairment of thermogenic phenotype in maturing and adult mice. Data presented as mean \pm SE, $n=14$ (VEH), 15 (DDTs) or 7 (p,p'-DDE) non-littermates/group at each time point. Statistical significance $\left(*=D D T s, \#=p, p^{\prime}\right.$-DDE) at $p<0.05$ vs age-matched Veh control. Veh, vehicle (organic olive oil); DDT, dichlorodiphenyltrichloroethane; DDE, dichlorodiphenyldichloroethylene; GD11.5, gestational day 11.5; P5, postnatal day 5; wks, weeks; mo, months; IF, immunofluorescence

Previously, perinatal exposure to DDTs significantly reduced adaptive energy expenditure and thermogenesis in six-month-old female mice [8]. To determine if this effect was BAT-autonomous, we tested whether mimicking sympathetic stimulation of adaptive thermogenesis by administering the B3AR agonist CL316,243 [49] rescued the effects of DDTs on respiration. Perinatal DDTs exposure reduced basal heat production in 4-month-old female mice (Fig. 3a), as previously observed in sixmonth-old female mice exposed to an identical dose and mixture of DDTs [8]. Basal oxygen consumption, an indirect measure of metabolism [42], was also reduced in four-month-old mice exposed perinatally to DDTs relative to controls (Fig. 3b). Metabolic impairment was observed in the absence of significant differences in physical activity between Veh control and DDTs mice (See Supplemental Fig. 1). Direct stimulation of brown adipocytes by CL 316,243 rescued measures of indirect calorimetry in DDTs-exposed animals with a significant interaction between acute CL 316,243 treatment and perinatal DDTs. Heat production was lower in DDTsexposed mice compared to controls, but DDTs animals treated with CL 316,243 responded at the same level as Veh control animals (Fig. 3a). Likewise, basal oxygen consumption in DDTs-exposed animals treated with CL 316,243 were similar to Veh controls (Fig. 3b).

The observation that acute stimulation of $\beta 3$ adrenergic receptors with CL (Fig. 3) restored normotypic metabolic responses in female mice exposed perinatally to DDTs suggested that DDTs target mechanisms that regulate BAT metabolism upstream of the $\beta 3$-adrenergic receptor, such as catecholamines $[50,51]$. Thus, we next quantified total concentrations $\mathrm{NE}$ and the primary NE metabolite, DHPG in BAT to examine whether effects of DDTs on respiration (Fig. 3) were mediated by decreased release of norepinephrine from sympathetic nerve terminals innervating BAT. HPLC analysis revealed no detectable differences in total NE (Fig. 4a) or DHPG (Fig. 4b) concentrations in BAT from control versus DDTs- or p,p'-DDE -exposed female mice (Fig. 4a). The ratio of [NE]:[DHPG] was also evaluated as a metric of intraneuronal turnover [52], but similarly did not reveal significant differences between groups (Fig. 4c).

The absence of an obvious neurochemical aberration in BAT (Fig. 4) but the rescue of DDTs-impaired respiration by pharmacologic agonism of the $\beta 3$ receptor (Fig. 3) suggested the possibility that perinatal DDTs interfere with morphologic determinants of sympathetic innervation of BAT. To address this, we first investigated the effects of perinatal DDTs and p,p'-DDE on the density of sympathetic axons in BAT from adult female mice. BAT was immunostained for tyrosine hydroxylase (TH) and neuropeptide $\mathrm{Y}$ (NPY) to distinguish sympathetic axons that innervated brown adipocytes ( $\mathrm{TH}$ immunopositive) from those that innervated the perivascular system (immunopositive for both TH and NPY) [53, 54]. The DDTs exposure significantly reduced sympathetic innervation in 4-month-old BAT by approximately $20 \%$ relative to control levels (Fig. 5b, Supplemental Table 2). 


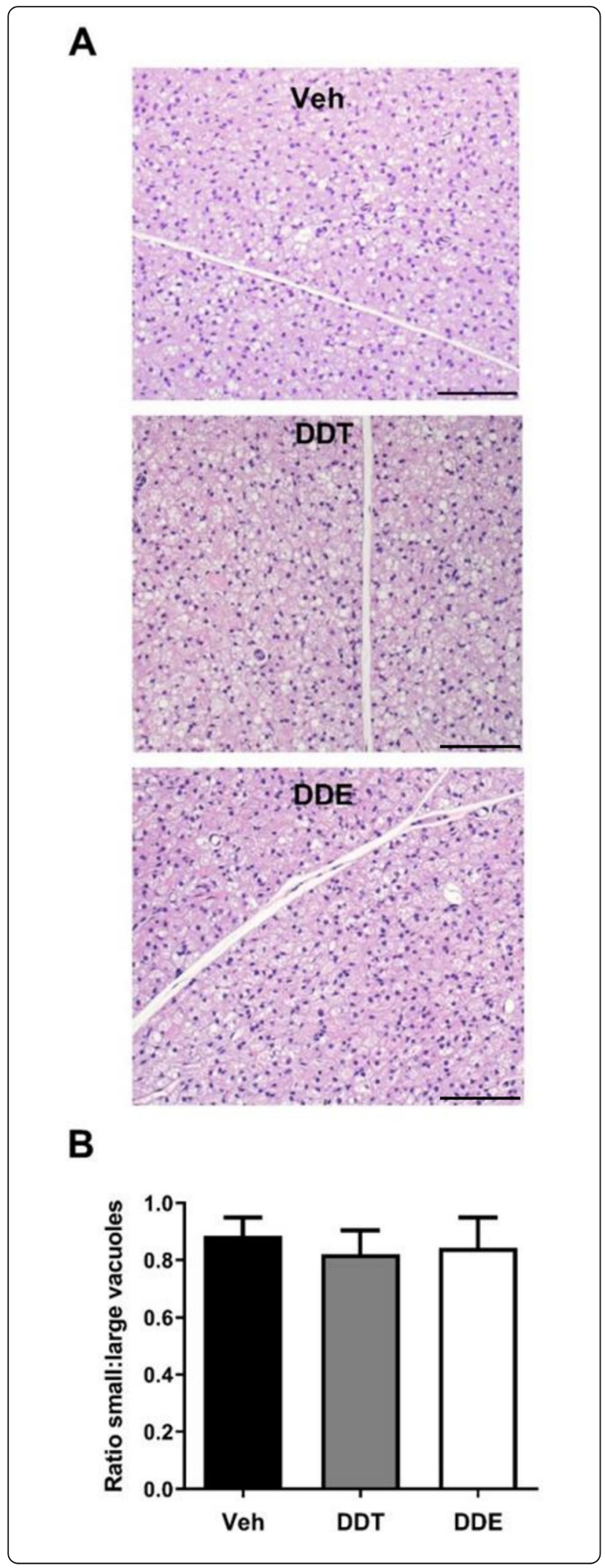

Fig. 2 Early-life exposure to DDTs or p,p'-DDE did not alter BAT morphology in adult female mice. a Representative images of H\&Estained BAT from 4-month-old female mice. Scale bar $=100 \mu \mathrm{m}$. $\mathbf{b}$ Quantification of H\&E-stained BAT morphology as the ratio of cells with small to large vacuoles, $n=3$ sections per sample, with $n=7$ animals per group used to calculate mean values. All data presented as mean \pm SE. No significant differences between groups were identified using one-way ANOVA with $p$ set at 0.05 . Veh, vehicle (organic olive oil); DDT, dichlorodiphenyltrichloroethane; DDE, dichlorodiphenyldichloroethylene

Decreased innervation of BAT appeared to be driven by DDTs specifically as innervation of p,p'-DDE -exposed BAT was not significantly different from that of Vehexposed mice (Fig. 5).

Sympathetic tone is determined not only by the density of sympathetic axons innervating target tissue, but also by the density of synaptic contacts between preand post-ganglionic neurons $[55,56]$. BAT is predominantly innervated by the stellate ganglia [16, 57]; therefore, we quantified synaptic connectivity in stellate from adult female mice via immunohistochemical colocalization of the presynaptic marker, Bassoon (Bas), and the postsynaptic marker, postsynaptic density 93 (PSD93) [58, 59]. Perinatal exposure to either DDTs or p,p'-DDE reduced synaptic density in the stellate ganglia by approximately 48 and $43 \%$, respectively, compared to controls (Fig. 6, Supplemental Table 2).

DDT and DDE concentrations in BAT in the current study were quantified in male offspring at 4 months post-exposure. The primary metabolite detected in the DDTs-administered group was p,p'-DDT, at a low concentration of $1.518 \mathrm{ng} / \mathrm{g}$ BAT (Table 2). A roughly $10 \%$ reduction in the proportion of o,p'-DDT was detected than was administered, consistent with its more rapid metabolism. BAT from p,p'-DDE-administered mice showed even less accumulation, with only $0.570 \mathrm{ng} / \mathrm{g}$ of the most concentrated metabolite, p,p'-DDE, accounting for nearly $74.3 \%$ of all measured DDT and DDE isoforms. p,p'-DDE was found only in BAT of mice for which it was administered. Consistent with the degradation of p,p'-DDE into o,p'-DDE [60, 61], some o,p'-DDE was also detected.

$\mathrm{BAT}=$ brown adipose tissue; $\mathrm{SE}=$ standard error; LOD $=$ limit of detection .

\section{Discussion}

In this work we demonstrate that oral gavage with p,p'DDE alone mimics thermogenic effects previously reported in 6-month-old female mice with combined perinatal exposure to DDTs [8], which we now show can be observed as early as 11 weeks after birth. While prevailing hypotheses of the mechanism(s) by which environmental obesogens alter metabolism have primarily 

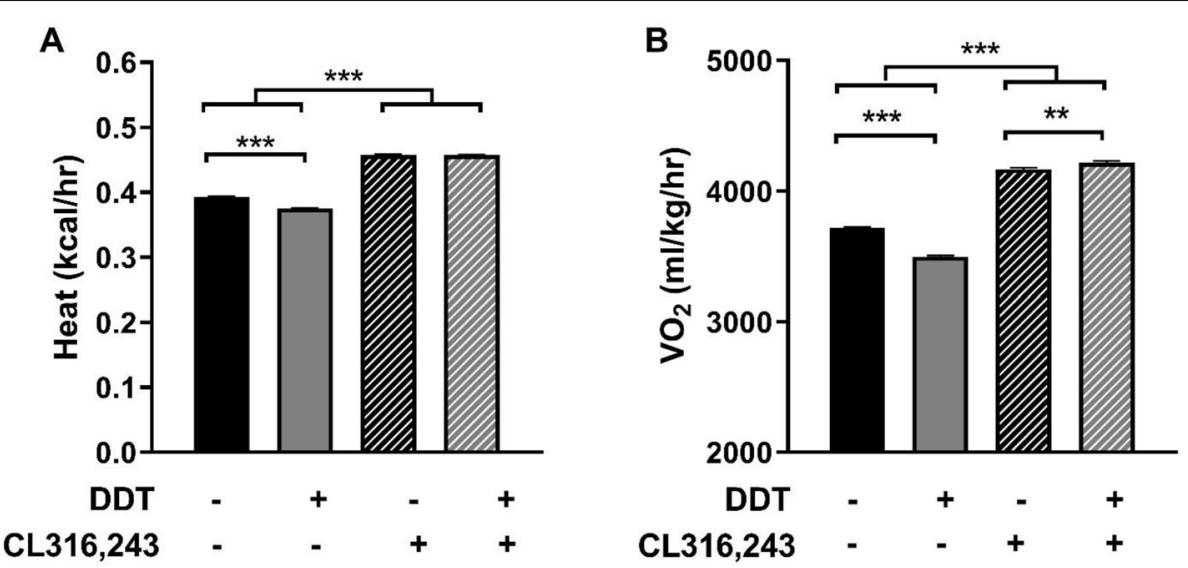

Fig. 3 Perinatal exposure to DDTs alters metabolism in 4-month-old female mice. Indirect calorimetry measurements for $\mathbf{a}$ heat and $\mathbf{b}$ oxygen consumption following IP injection with $\beta 3 A R$ agonist CL 316,243 $(0.1 \mathrm{mg} / \mathrm{kg})$ or PBS, recorded and averaged from minute 11 to minute 31 postinjection. Data presented as mean $\pm \mathrm{SE}, \mathrm{n}=7$ animals per group. Indirect calorimetry-derived parameters were modeled with the fixed effects of perinatal exposure, acute (agonist or Veh) exposure, and their interaction, while accounting for the repeated measures from individual mice and resulting covariance structure in a mixed linear model that allows the data to exhibit within- individual correlation (PROC MIXED, SAS v9.4). Significance thresholds were $p<0.05$ for main effects and $p<0.1$ for interaction effects, vs Veh. ${ }^{* *} p<0.001 ;{ }^{* *} p<0.01$.

DDT, dichlorodiphenyltrichloroethane

focused on physiological and metabolic dysfunction in adipose tissue; our findings identify modulation of synaptic connectivity in sympathetic circuits that regulate $\mathrm{BAT}$ as an additional, novel mechanism contributing to the effects of DDTs and p,p'-DDE on thermogenesis.

The observation that administration of DDTs or p,p'DDE during the perinatal period each persistently reduced thermogenesis in adult female mice is consistent with reports that obesity is correlated with exposures to DDT or DDE $[4,6,62]$ and with reduced thermogenesis $[63,64]$. While exposure to mixtures of DDTs and p,p'DDE have been previously shown to reduce the body temperature of adult mice and rats $[8,62]$, this is the first study to demonstrate that administration of p,p'DDE alone can cause such an effect.

Our data strongly support the hypothesis that the thermogenic defect observed in female mice perinatally exposed to DDTs or p,p'-DDE is mediated by perturbation of sympathetic regulation of BAT. The most direct evidence of this is the observation that pharmacologic agonism of $\beta 3$ adrenergic receptors rescued DDTsrelated impairments in heat production and oxygen consumption. $\beta 3$ adrenergic receptors are highly expressed in brown adipose tissue where they function to regulate lipolysis [16], as indicated by reports of decreased oxygen consumption in NE-stimulated $\beta 3-\mathrm{KO}$ mice [65]. Collectively, these observations suggest that DDTs impair thermogenesis by targeting mechanisms of thermogenesis upstream of adipose tissue. Unfortunately there was no remaining BAT to evaluate its UCP1 expression, a protein predominantly responsible for the tissue's thermogenic properties [66], but future studies should examine whether DDTs or p,p'-DDE cause brown adipocyte-autonomous uncoupling of respiration.

BAT thermogenesis is regulated by the sympathetic nervous system [16], and a recent report demonstrates that BAT thermogenesis can be modulated by influences on peripheral sympathetic neurons independent of input from CNS centers [67], Sympathetic tone at the level of the target tissue is strongly influenced by the density of sympathetic innervation of the target tissue and by the extent of dendritic arborization of the postganglionic neurons [68]. As determined using quantitative immunohistochemistry, sympathetic innervation of BAT was significantly reduced in four-month-old female mice perinatally exposed to DDTs. However, a similar effect was not observed in p,p'-DDE-exposed animals. In contrast, perinatal exposure to either DDTs or p,p'-DDE significantly reduced synapse density in stellate ganglia of four-month-old female mice. There is a direct relationship between synapse density in sympathetic ganglia and the size of the dendritic arbor of postganglionic sympathetic neurons $[57,69]$. Therefore, the significantly reduced synapse density in stellate ganglia from female mice perinatally exposed to either DDTs or p,p'-DDE is an indication that developmental exposure to these chemicals decreases dendritic arborization in stellate sympathetic neurons. Collectively, our data suggest that DDTs and p,p'-DDE impair thermogenesis via convergent (decreased dendritic arborization of postganglionic neurons) and divergent (decreased innervation of BAT) sympathetic mechanisms. This is consistent with literature demonstrating that axons and dendrites are differentially regulated, particularly during development [68]. 


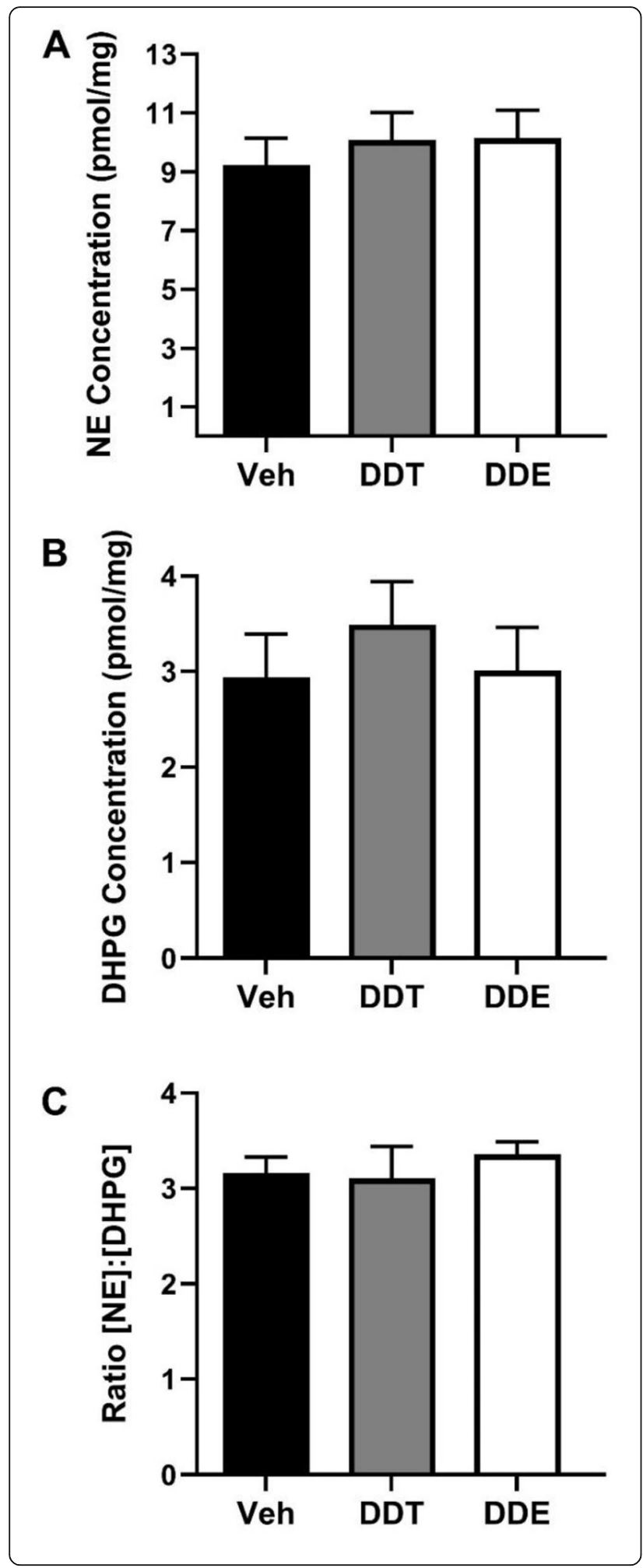

Fig. 4 Perinatal DDTs or p,p'-DDE exposure doesn't significantly alter BAT catecholamine levels in adult female mice. Concentration of a norepinephrine (NE), its metabolite $\mathbf{b} \mathrm{DHPG}$, and $\mathbf{c}$ the ratio of NE:DHPG in BAT were determined using HPLC from $n=7$ animals per treatment, age 4 months. No significant differences between groups were identified using ANOVA with $p$ set at 0.05. BAT, brown adipose tissue; Veh, vehicle (organic olive oil); DDT, dichlorodiphenyltrichloroethane; DDE, dichlorodiphenyldichloroethylene; NE, norepinephrine; DHPG, dihydroxyphenylglycine

Whether DDTs and p,p'-DDE interfere with the synaptic connectivity of peripheral sympathetic neurons via direct neurotoxic effects on neurons or by altering target influences on dendritic and axonal morphogenesis of sympathetic neurons $[68,70]$ remains to be determined.

DDT and DDE differ in the potency of their interactions with sex steroid receptors with o,p'DDT exhibiting 7-10x greater potency at the estrogen receptor (ER) [71-73], and with p,p'-DDE considered primarily an antagonist of the androgen receptor [74-76]. It is unlikely that androgen receptor antagonism influenced the sympathetic thermogenic program given prenatal testosterone decreases heat production in adult female mice [77]. However, there is extensive evidence that estrogen modulates peripheral sympathetic neuroeffector activity related to the thermogenic program [78-80]. For example, reduced sympathetic innervation of the vasculature by decreasing levels of nerve growth factor (NGF) in both the sympathetic ganglia and target tissue [81]. This suggest the possibility that disparate effects between developmental exposure to DDTs versus p,p'-DDE exposure groups on sympathetic innervation of BAT may be mediated the pro-estrogenic signaling of o,p'DDT to lower relevant tissue levels of NGF in DDTs-exposed groups. While this hypothesis has yet to be investigated, ER activation likely does not contribute to effects on thermogenesis or synaptic density in stellate ganglia since these outcomes were observed in female mice exposed developmentally to either the DDTs or p,p'-DDE.

Adaptive thermogenesis by BAT is triggered by release of NE from postganglionic sympathetic neurons [82], and NE levels in BAT under steady-state conditions have historically been used as a direct index of SNS innervation of BAT [83]. We did not observe any significant effects of DDTs or p,p'-DDE on NE or DHPG levels in BAT from 4-month old female mice. Quantification of NE turnover as indicated by the ratio [NE]:[DHPG] similarly revealed no significant DDTs effect. The reason for the apparent disconnect between DDTs-related effects on morphologic determinants of synaptic connectivity versus NE levels in BAT are unknown. One possibility is that under basal conditions, postganglionic sympathetic neurons in adult female mice perinatally exposed to DDTs synthesize and/or release more NE than Veh 
A
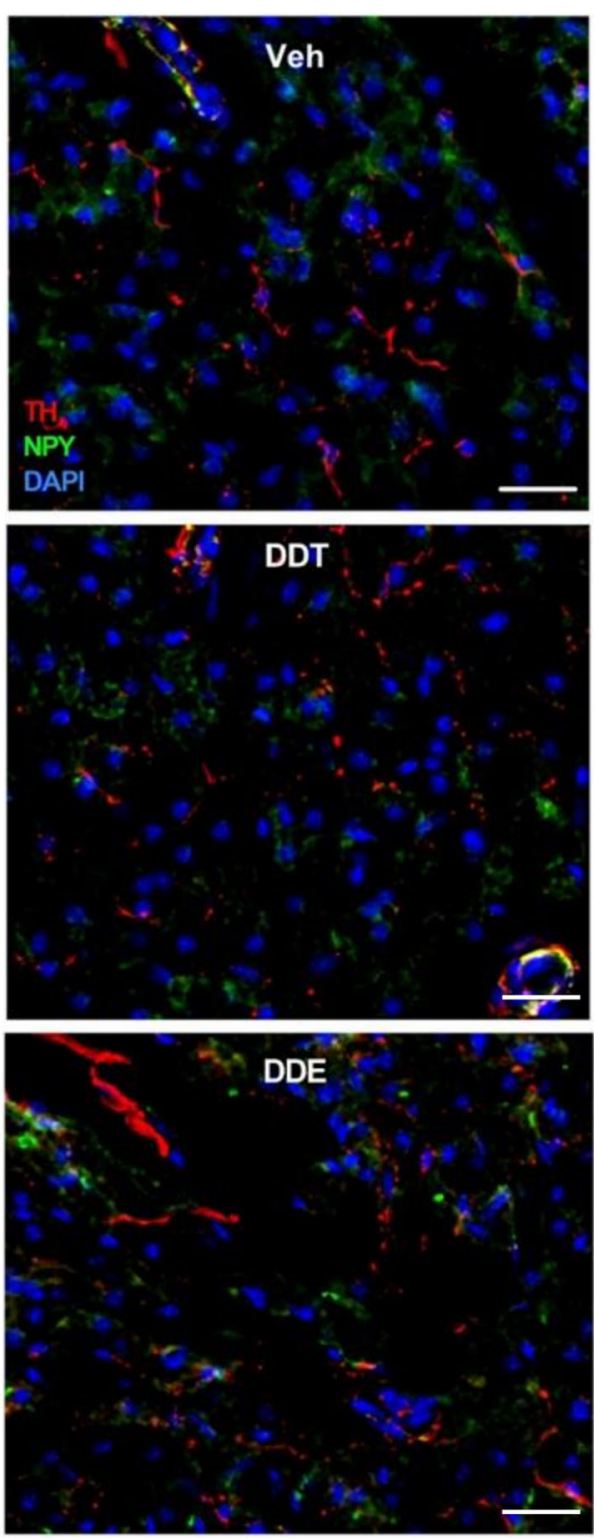

B

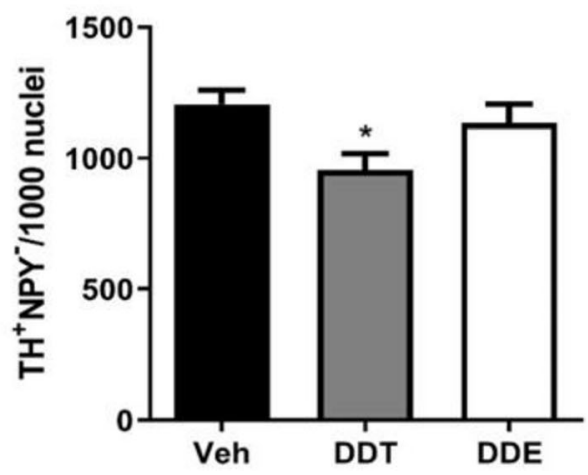

Fig. 5 Perinatal exposure to DDTs decreased sympathetic innervation of BAT in adult female mice. a Representative images of BAT immunostained for tyrosine hydroxylase $(T H$, red), neuropeptide Y (NPY, green), and counterstaining with DAPI to identify cell nuclei. Fibers immunopositive for TH but not NPY innervate BAT; fibers immunopositive for both TH and NPY innervate blood vessels. Scale bar $=25 \mu \mathrm{m}$. $\mathbf{b}$ Quantification of adrenergic innervation as determined by $\%$ area TH+/NPY- per ROI, with $n=4-8$ ROls averaged per sample and $n=6-7$ animals per treatment used to calculate the mean. Data represented as mean positive

immunoreactivity per ROI normalized per 1000 DAPI+ nuclei \pm SE. Statistical significance determined by one-way ANOVA with post hoc Tukey's test. ${ }^{*} p<0.05$ vs Veh. BAT, brown adipose tissue; Veh, vehicle (organic olive oil); DDT, dichlorodiphenyltrichloroethane;

DDE, dichlorodiphenyldichloroethylene

control animals to compensate for decreased synaptic density, but they are unable to respond appropriately to thermogenic triggers. Arguing against this possibility is a previous report that perinatal exposure to environmentally relevant levels of DDT decreases NE levels in the systemic circulation of prepubertal and adult rats [21]. A second possibility is the potential contribution of $\mathrm{NE}$ from sources other than sympathetic neurons, such as BAT-associated macrophages and paracrine signaling from white adipocytes [84, 85]. While the lack of effect on NE and DHPG levels in BAT suggest that DDTs and p,p'-DDE do not impair thermogenesis by altering NE synthesis, release, or uptake in sympathetic terminals that innervate BAT, further studies are needed to confirm this conclusion.

Tonic activity in postganglionic sympathetic neurons is strongly correlated with dendritic arborization [55, 86]. Thus, the significant decrease in synaptic density observed in stellate ganglia of DDTs and p,p'-DDE-exposed mice suggests that these perinatal exposures led to persistent attenuation of tonic activity and subsequently impaired thermogenic signaling. To our knowledge, this is the first evidence to support the hypothesis that administration of DDTs and p,p'-DDE impair thermogenesis by reducing synaptic density in sympathetic circuits that regulate BAT. This proposed mechanistic model is supported by previous reports that sympathetic denervation of BAT significantly impaired thermogenesis and energy balance coincident with increased body mass in rodents [24-29]. Conversely, an increased number of sympathetic ganglionic cells innervating BAT has been reported in mice postnatally exposed to cold $\left(18^{\circ} \mathrm{C}\right)$, which correlated with increased $\mathrm{NE}$ concentration in BAT and two-fold higher sympathetic nerve activity to BAT [87].

Despite no observed changes to the thermoneutral zone or NE levels in BAT, basal heat production was attenuated in female mice exposed to DDTs versus Veh while also exposed to mild cold stress $\left(21-23^{\circ} \mathrm{C}\right)$. 


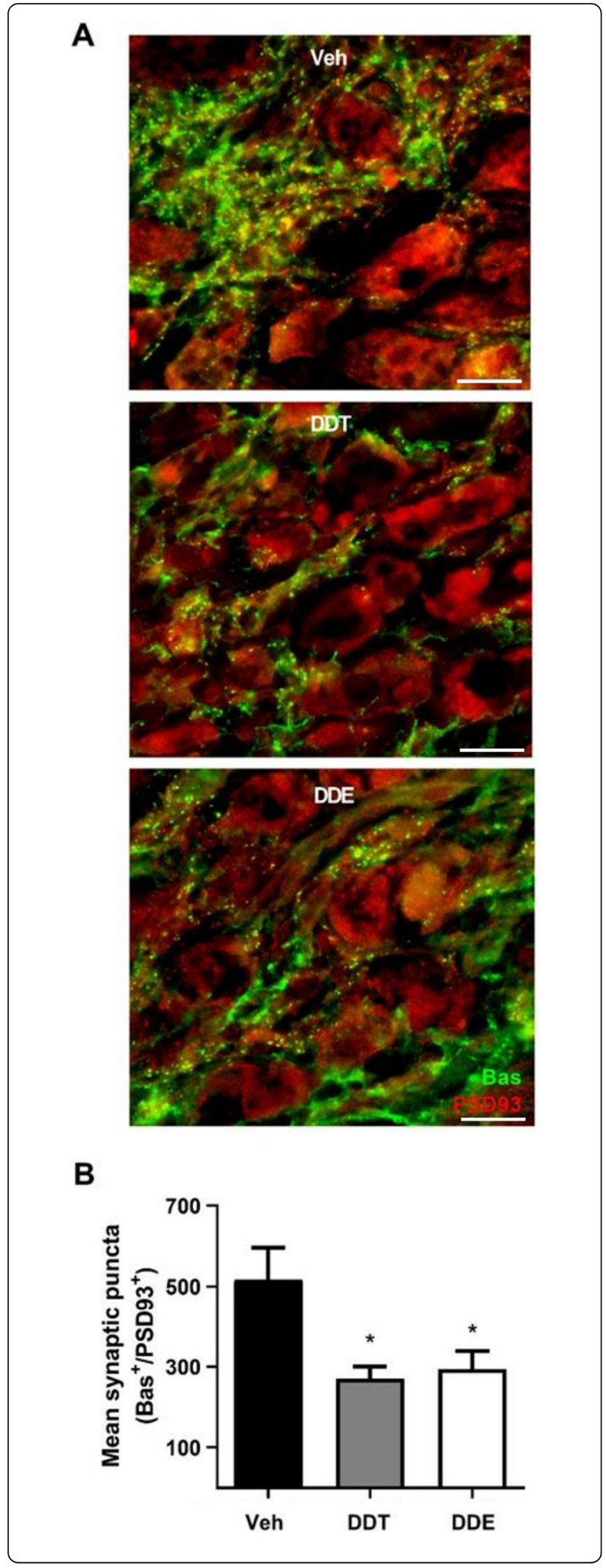

Fig. 6 Perinatal DDTs and p,p'-DDE exposure decreased synaptic density in stellate ganglia of 4-month-old female mice. a

Representative images of stellate ganglia stained for synaptic puncta, identified by co-localization of the presynaptic marker Bassoon (Bas, green) and the postsynaptic marker PSD93 (red). Scale bar $=14 \mu \mathrm{m}$. b Quantification of mean synaptic puncta per ROI, with $n=6-9$ ROIs averaged per sample and 4-5 animals per treatment used to calculate the mean. Data presented as mean \pm SE. Statistical significance determined by one-way ANOVA with post hoc Tukey's test. * $p<0.05$ vs Veh. Veh, vehicle (organic olive oil); DDT, dichlorodiphenyltrichloroethane; DDE,

dichlorodiphenyldichloroethylene; Bas, Bassoon; PSD93, postsynaptic density 93

Impairments in the expected minor sympathetic activation of BAT under mild cold stressed [31] may have further limited the thermogenic capacity of females administered DDTs. Future studies might utilize thermoneutrality as an environmental temperature at which sympathetic input to BAT is minimal [88] to further explore sex-specific thermogenic sympathetic activity and its relation to DDTs- and p,p'DDE-related female susceptibility.

The observation that p,p'-DDE alone reduces body temperature is relevant to long term human exposures. Due to their lipophilicity, DDTs and p,p'-DDE persistently accumulate in adipose tissue, with human elimination half-lives estimated to be 2.1 years and 7.6 years, respectively [89]. DDE concentrations observed in BAT of four-month-old female mice exposed perinatally to $\mathrm{p}, \mathrm{p}^{\prime}$-DDE were over ten-fold lower than $\mathrm{p}, \mathrm{p}^{\prime}$-DDE levels in the adipose tissue (median p,p'-DDE concentrations of $5.64 \mathrm{ng} / \mathrm{g}$ and $9.17 \mathrm{ng} / \mathrm{g}$ in visceral and subcutaneous adipose tissue, respectively) of adolescents undergoing bariatric surgery in Cincinnati, Ohio, where p,p'-DDE exposure presumably comes from diet and the environment rather than metabolized p,p'-DDT [90]. In addition, DDT and DDE concentrations observed in BAT of four-month-old female mice exposed perinatally to DDTs and p,p'-DDE were 4000 to 27,000 times, respectively, lower than levels in the adipose

Table 2 DDT metabolite concentration in brown adipose of 4month-old female mice perinatally exposed to DDTs or $p, p^{\prime}-D D E$

\begin{tabular}{lcc}
\hline & $\begin{array}{c}\text { DDTs dose group } \\
(\mathbf{n}=\mathbf{3})\end{array}$ & $\begin{array}{c}\mathbf{p}, \mathbf{p}^{\prime}-\mathrm{DDE} \text { dose group } \\
(\mathbf{n}=\mathbf{3})\end{array}$ \\
$\begin{array}{lcc}\text { Measured } \\
\text { Metabolite }\end{array}$ & $\begin{array}{c}\text { mean } \pm \text { SE }(\mathbf{n g} / \mathbf{g} \text { BAT }) \\
\text { mean } \pm \mathbf{S E}(\mathbf{n g} / \mathbf{g} \text { BAT })\end{array}$ \\
\hline p, $\mathrm{p}^{\prime}-\mathrm{DDT}$ & $1.518 \pm 0.373$ & $0.027 \pm 0.001$ \\
$\mathrm{p}, \mathrm{p}^{\prime}-\mathrm{DDE}$ & $<\mathrm{LOD}$ & $0.570 \pm 0.066$ \\
$\mathrm{o}, \mathrm{p}^{\prime}-\mathrm{DDT}$ & $0.217 \pm 0.024$ & $<\mathrm{LOD}$ \\
$\mathrm{O}, \mathrm{p}^{\prime}-\mathrm{DDE}$ & $<\mathrm{LOD}$ & $0.170 \pm 0.024$ \\
\hline
\end{tabular}


(5910 ng/g maternal subcutaneous adipose for the sum of DDT and metabolites) of Kenyan mothers immediately after birth [91], which could have resulted from the metabolism of DDT into DDE in addition to direct DDE exposure. The comparatively low levels of accumulated DDTs and p,p'-DDE in BAT of four-monthold mice corroborate the hypothesis that even low levels of exposures are associated with persistent thermogenic impairment of BAT.

\section{Conclusions}

The data presented herein support the hypothesis of developmental origins of health and disease $(\mathrm{DOHaD})$ in the context of metabolic dysfunction and obesity [92] Specifically, we describe novel data indicating that perinatal exposure to DDTs or p,p'-DDE interferes with the development of the sympathetic circuits that regulate BAT thermogenic activity in adulthood. While various environmental exposures and altered conditions during the perinatal period have been shown to cause sustained changes in the neural regulation of thermogenic systems in animal models [83, 87, 93, 94], ours is the first study to implicate changes in sympathetic neuromodulation as a mechanism contributing to the effects of perinatal exposure to DDTs or p,p'-DDE on thermogenic impairment later in life. Further, in contrast to the traditional epigenetic focus of many DOHaD studies [95-97], these data add to a growing literature identifying the reprogramming of neural circuitry, in this case, altered wiring of the peripheral nervous system, during a critical window of development as an alternative mechanism in the developmental origins of environmentally-induced obesity.

\section{Abbreviations}

AR: adrenergic receptor; BAT: brown adipose tissue; CLAMS: comprehensive lab animal monitoring system; DAPI: 4',6-diamidino-2-phenylindole,; DDT: dichlorodiphenyltrichloroethane;

DDE: dichlorodiphenyldichloroethylene; DHPG: dihydroxyphenylglycine; DIT: developmental impaired thermogenesis; DOHaD: developmental origins of health and disease; GC: gas chromatography; GD: gestational day; HPLC: high performance liquid chromatography; IACUC: institutional animal care and use committee; IP: intraperitoneal injection; LCT: lower critical temperature; LOD: limits of detection; MS: mass spectrometry; NE: norepinephrine; NPY: neuropeptide Y; OCT: optimal cutting temperature; PBS: phosphate-buffered saline; PFA: paraformaldehyde; PND: postnatal day; PSD93: postsynaptic density 93; ROI: region of interest; RT: room temperature; SC: subcutaneous; SE: standard error of the mean; SNS: sympathetic nervous system; ST: stellate ganglia; UCP1: uncoupling protein 1; UCT: upper critical temperature; T2D: type II diabetes; TH: tyrosine hydroxylase; TNZ: thermoneutral zone; Veh: vehicle

\section{Supplementary Information}

The online version contains supplementary material available at https://doi. org/10.1186/s12940-021-00721-2.

Additional File 1: Supplemental Table 1. Analysis of Thermoneutral Zone. Supplemental Fig. 1. Quantification of mouse physical activity. Supplemental Table 2. Summary of key results by exposure

\section{Acknowledgements}

The authors would like to acknowledge Dr. Stephen Griffey for his advice, edits, and technical expertise in histopathological analyses. The Energy Expenditure ANCOVA analysis was provided by the NIDDK Mouse Metabolic Phenotyping Centers (MMPC, www.mmpc.org) using their Energy Expenditure Analysis page (http://www.mmpc.org/shared/regression.aspx). We would also like to thank Jon Ramsey (MMPC) for his assistance with indirect calorimetry.

\section{Authors' contributions}

$\mathrm{PL}$ and MLM designed the experiment and supervised the work. MLM, SE, and $\mathrm{KJ}$ performed the experiments and assisted with sample collection. $M L M, S E, K J, A V E, B H, K M$, and KP processed the experimental data and performed analyses. BH performed catecholamine analyses. KM and KP performed DDT and DDE isomer quantification using GC-MS analysis. AVE performed immunofluorescence analyses, drafted the manuscript, and designed the figures. PL, MLM, and AVE contributed to the interpretation of the results. All authors read, edited, and approved the final manuscript.

\section{Funding}

Funding for this research was provided by NIEHS (grant \# R01 ES024946 and \# T32 ES007059) and NHLBI (R01) HL093056. This research used the Biological Analysis Core of the UC Davis MIND Institute Intellectual and Developmental Disabilities Research Center (U54 HD079125) and the UC Davis MMPC Energy Balance, Exercise, \& Behavior Core (NIH grant U24DK092993). The funders had no role in study design, data collection and analysis, decision to publish, or preparation of the manuscript.

\section{Availability of data and materials}

The datasets used and/or analyzed during the current study are available from corresponding author on reasonable request.

\section{Declarations}

Ethics approval and consent to participate

All animal experiments were approved by the UC Davis Institutional Animal Care and Use Committee (IACUC protocol \#18938), and were conducted in accordance with the ARRIVE guidelines and the National Institutes of Health guide for the care and use of laboratory animals (NIH publication No. 8023, revised 1978).

Consent for publication

Not applicable.

\section{Competing interests}

The authors declare they have no competing interests.

\section{Author details}

'Department of Environmental Toxicology, University of California-Davis College of Agricultural and Environmental Sciences, One Shields Avenue, Davis, CA 95616, USA. ${ }^{2}$ Department of Molecular Biosciences, University of California-Davis, School of Veterinary Medicine, 1089 Veterinary Medicine Drive, Davis, CA 95616, USA. ${ }^{3}$ Present address: Office of Environmental Health Hazard Assessment, California EPA, Oakland, CA, USA. ${ }^{4}$ Integrative Genetics and Genomics Graduate Group, University of California-Davis, Davis, CA, USA. ${ }^{5}$ Department of Chemical Physiology and Biochemistry, Oregon Health \& Science University, 3181 SW Sam Jackson Park Road, Portland, OR 97239, USA. ${ }^{6}$ School of Engineering, Brown University, 184 Hope Street, Providence, RI 02912, USA.

Received: 16 September 2020 Accepted: 15 March 2021 Published online: 01 April 2021

\section{References}

1. Uwimana A, Legrand E, Stokes BH, Ndikumana JM, Warsame M, Umulisa N, et al. Emergence and clonal expansion of in vitro artemisinin-resistant plasmodium falciparum kelch13 R561H mutant parasites in Rwanda. Nat Med. 2020;26(10):1602-8. https://doi.org/10.1038/s41591-020-1005-2.

2. Hu X, Li S, Cirillo P, Krigbaum N, Tran V, Ishikawa T, la Merrill MA, Jones DP, Cohn B. Metabolome wide association study of serum DDT and DDE in 
pregnancy and early postpartum. Reprod Toxicol. 2020;92:129-37. https:// doi.org/10.1016/j.reprotox.2019.05.059.

3. Nadal A, Quesada I, Tuduri E, Nogueiras R, Alonso-Magdalena P. Endocrinedisrupting chemicals and the regulation of energy balance. Nat Rev Endocrinol. 2017;13(9):536-46. https://doi.org/10.1038/nrendo.2017.51.

4. Di Cesare M, Soric M, Bovet P, Miranda JJ, Bhutta Z, Stevens GA, et al. The epidemiological burden of obesity in childhood: a worldwide epidemic requiring urgent action. BMC Med. 2019;17(1):212. https://doi.org/10.1186/ s12916-019-1449-8.

5. Baillie-Hamilton PF. Chemical toxins: a hypothesis to explain the global obesity epidemic. J Altern Complement Med. 2002;8(2):185-92. https://doi. org/10.1089/107555302317371479.

6. Cano-Sancho G, Salmon AG, La Merrill MA. Association between Exposure to p,p'-DDT and Its Metabolite p,p'-DDE with Obesity: Integrated Systematic Review and Meta-Analysis. Environ Health Perspect 2017;125(9):096002, Association between Exposure top,p'-DDT and Its Metabolitep,p'-DDE with Obesity: Integrated Systematic Review and Meta-Analysis, DOl: https://doi. org/10.1289/EHP527.

7. Song Y, Chou EL, Baecker A, You NC, Song Y, Sun Q, et al. Endocrinedisrupting chemicals, risk of type 2 diabetes, and diabetes-related metabolic traits: a systematic review and meta-analysis. J Diabetes. 2016;8(4):516-32. https://doi.org/10.1111/1753-0407.12325.

8. La Merrill M, Karey E, Moshier E, Lindtner C, La Frano MR, Newman JW, et al. Perinatal exposure of mice to the pesticide DDT impairs energy expenditure and metabolism in adult female offspring. PLoS One. 2014;9(7):e103337. https://doi.org/10.1371/journal.pone.0103337.

9. Landsberg L. Core temperature: a forgotten variable in energy expenditure and obesity? Obes Rev. 2012;13(Suppl 2):97-104. https://doi.org/10.1111/j.14 67-789X.2012.01040.x.

10. Ouellet V, Routhier-Labadie A, Bellemare W, Lakhal-Chaieb L, Turcotte E, Carpentier AC, et al. Outdoor temperature, age, sex, body mass index, and diabetic status determine the prevalence, mass, and glucose-uptake activity of 18F-FDG-detected BAT in humans. J Clin Endocrinol Metab. 2011;96(1): 192-9. https://doi.org/10.1210/jc.2010-0989.

11. Matsushita M, Yoneshiro T, Aita S, Kameya T, Sugie H, Saito M. Impact of brown adipose tissue on body fatness and glucose metabolism in healthy humans. Int J Obes. 2014;38(6):812-7. https://doi.org/10.1038/ ijo.2013.206.

12. Chiang SH, Bazuine M, Lumeng CN, Geletka LM, Mowers J, White NM, Ma JT, Zhou J, Qi N, Westcott D, Delproposto JB, Blackwell TS, Yull FE, Saltiel AR The protein kinase IKKepsilon regulates energy balance in obese mice. Cell. 2009;138(5):961-75. https://doi.org/10.1016/j.cell.2009.06.046.

13. Klaus $\mathrm{S}$, Munzberg $H$, Truloff $C$, Heldmaier G. Physiology of transgenic mice with brown fat ablation: obesity is due to lowered body temperature. Am J Phys. 1998;274(2):R287-93.

14. Saito M, Okamatsu-Ogura Y, Matsushita M, Watanabe K, Yoneshiro T, NioKobayashi J, Iwanaga T, Miyagawa M, Kameya T, Nakada K, Kawai Y, Tsujisaki M. High incidence of metabolically active brown adipose tissue in healthy adult humans: effects of cold exposure and adiposity. Diabetes. 2009;58(7): 1526-31. https://doi.org/10.2337/db09-0530.

15. Liu X, Wang S, You Y, Meng M, Zheng Z, Dong M, Lin J, Zhao Q, Zhang C, Yuan X, Hu T, Liu L, Huang Y, Zhang L, Wang D, Zhan J, Jong Lee $H$, Speakman JR, Jin W. Brown adipose tissue transplantation reverses obesity in Ob/Ob mice. Endocrinology. 2015;156(7):2461-9. https://doi.org/10.1210/ en.2014-1598.

16. Cannon B, Nedergaard J. Brown adipose tissue: function and physiological significance. Physiol Rev. 2004;84(1):277-359. https://doi.org/10.1152/ physrev.00015.2003.

17. Pestana D, Teixeira D, Meireles M, Marques C, Norberto S, Sa C, et al. Adipose tissue dysfunction as a central mechanism leading to dysmetabolic obesity triggered by chronic exposure to p,p'-DDE. Sci Rep 2017;7(1):2738, Adipose tissue dysfunction as a central mechanism leading to dysmetabolic obesity triggered by chronic exposure to p,p'-DDE, DOl: https://doi.org/10.1 038/s41598-017-02885-9.

18. Cypess AM, Kahn CR. Brown fat as a therapy for obesity and diabetes. Curr Opin Endocrinol Diabetes Obes. 2010;17(2):143-9. https://doi.org/10.1097/ MED.0b013e328337a81f.

19. Ukropec J, Ukropcova B, Kurdiova T, Gasperikova D, Klimes I. Adipose tissue and skeletal muscle plasticity modulates metabolic health. Arch Physiol Biochem. 2008;114(5):357-68. https://doi.org/10.1080/138134 50802535812
20. Zhorov BS, Dong K. Elucidation of pyrethroid and DDT receptor sites in the voltage-gated sodium channel. Neurotoxicology. 2017;60:171-7. https://doi. org/10.1016/j.neuro.2016.08.013.

21. Yaglova NV, Tsomartova DA, Yaglov W. Effect of prenatal and postnatal exposure to low doses of DDT on catecholamine secretion in rats in different period of ontogeny. Bull Exp Biol Med. 2017;163(4):422-4. https:// doi.org/10.1007/s10517-017-3819-6.

22. Ferguson CA, Audesirk G. Effects of DDT and permethrin on neurite growth in cultured neurons of chick embryo brain and Lymnaea stagnalis. Toxicol in Vitro. 1990;4(1):23-30. https://doi.org/10.1016/0887-2333(90)90005-E.

23. Shinomiya N, Shinomiya M. Dichlorodiphenyltrichloroethane suppresses neurite outgrowth and induces apoptosis in PC12 pheochromocytoma cells. Toxicol Lett. 2003;137(3):175-83. https://doi.org/10.1016/S0378-4274 (02)00401-0.

24. Wolf $Y$, Boura-Halfon S, Cortese N, Haimon Z, Sar Shalom H, Kuperman $Y$, Kalchenko V, Brandis A, David E, Segal-Hayoun Y, Chappell-Maor L, Yaron A, Jung S. Brown-adipose-tissue macrophages control tissue innervation and homeostatic energy expenditure. Nat Immunol. 2017;18(6):665-74. https:// doi.org/10.1038/ni.3746.

25. Schulz TJ, Huang P, Huang TL, Xue R, McDougall LE, Townsend KL, et al. Brown-fat paucity due to impaired BMP signalling induces compensatory browning of white fat. Nature. 2013;495(7441):379-83. https://doi.org/10.103 8/nature11943.

26. Pulinilkunnil T, He H, Kong D, Asakura K, Peroni OD, Lee A, Kahn BB. Adrenergic regulation of AMP-activated protein kinase in brown adipose tissue in vivo. J Biol Chem. 2011;286(11):8798-809. https://doi.org/10.1074/ jbc.M111.218719.

27. Klingenspor M, Meywirth A, Stohr S, Heldmaier G. Effect of unilateral surgical denervation of brown adipose tissue on uncoupling protein mRNA level and cytochrom-c-oxidase activity in the Djungarian hamster. J Comp Physiol B. 1994;163(8):664-70. https://doi.org/10.1007/BF00369517.

28. Bartness TJ, Wade GN. Effects of interscapular brown adipose tissue denervation on body weight and energy metabolism in ovariectomized and estradiol-treated rats. Behav Neurosci. 1984;98(4):674-85. https://doi. org/10.1037/0735-7044.98.4.674.

29. Dulloo AG, Miller DS. Energy balance following sympathetic denervation of brown adipose tissue. Can J Physiol Pharmacol. 1984;62(2):235-40. https:// doi.org/10.1139/y84-035

30. Hylander BL, Repasky EA. Thermoneutrality, mice, and Cancer: a heated opinion. Trends Cancer. 2016;2(4):166-75. https://doi.org/10.1016/j.trecan.2 016.03.005.

31. David JM, Knowles S, Lamkin DM, Stout DB. Individually ventilated cages impose cold stress on laboratory mice: a source of systemic experimental variability. J Am Assoc Lab Anim Sci. 2013;52(6):738-44.

32. Speakman JR, Keijer J. Not so hot: optimal housing temperatures for mice to mimic the thermal environment of humans. Mol Metab. 2012;2(1):5-9. https://doi.org/10.1016/j.molmet.2012.10.002.

33. de Graaf-Peters VB, Hadders-Algra M. Ontogeny of the human central nervous system: what is happening when? Early Hum Dev. 2006;82(4):25766. https://doi.org/10.1016/j.earlhumdev.2005.10.013.

34. Derry DM, Daniel H. Sympathetic nerve development in the brown adipose tissue of the rat. Can J Physiol Pharmacol. 1970;48(3):160-8. https://doi.org/1 $0.1139 / y 70-028$

35. Feurer I, Mullen $J$. Bedside measurement of resting energy expenditure and respiratory quotient via indirect Calorimetry. Nutr Clin Pract. 2016; 1(1):43-9.

36. Muller TD, Lee SJ, Jastroch M, Kabra D, Stemmer K, Aichler M, et al. p62 links beta-adrenergic input to mitochondrial function and thermogenesis. J Clin Invest. 2013;123(1):469-78. https://doi.org/10.1172/JCI64209.

37. Li W, Knowlton D, Van Winkle DM, Habecker BA. Infarction alters both the distribution and noradrenergic properties of cardiac sympathetic neurons. Am J Physiol Heart Circ Physiol. 2004;286(6):H2229-36. https://doi.org/10.11 52/ajpheart.00768.2003.

38. Sastre E, Nicolay A, Bruguerolle B, Portugal H. Method for simultaneous measurement of norepinephrine, 3-methoxy-4-hydroxyphenylglycol and 3,4-dihydroxyphenylglycol by liquid chromatography with electrochemical detection: application in rat cerebral cortex and plasma after lithium chloride treatment. J Chromatogr B Analyt Technol Biomed Life Sci. 2004; 801(2):205-11. https://doi.org/10.1016/j.jchromb.2003.11.012.

39. Bayles RG, Olivas A, Denfeld Q, Woodward WR, Fei SS, Gao L, Habecker BA. Transcriptomic and neurochemical analysis of the stellate ganglia in mice 
highlights sex differences. Sci Rep. 2018;8(1):8963. https://doi.org/10.1038/ s41598-018-27306-3.

40. MacDougall D, Crummett WB. Et a. guidelines for data acquisition and data quality evaluation in environmental chemistry. Anal Chem. 2002; 52(14):2242-9.

41. Long GL, Winefordner JD. Limit of detection. A closer look at the IUPAC definition. Anal Chem. 2008;55(7):712A-24A.

42. Cannon B, Nedergaard J. Nonshivering thermogenesis and its adequate measurement in metabolic studies. J Exp Biol. 2011;214(Pt 2):242-53. https:// doi.org/10.1242/jeb.050989.

43. Gordon CJ. Thermal physiology of laboratory mice: defining thermoneutrality. J Therm Biol. 2012;37(8):654-85. https://doi.org/10.1016/j. jtherbio.2012.08.004

44. Abreu-Vieira G, Xiao C, Gavrilova O, Reitman ML. Integration of body temperature into the analysis of energy expenditure in the mouse. Mol Metab. 2015;4(6):461-70. https://doi.org/10.1016/j.molmet.2015.03.001.

45. Scholander PF, Hock R, Walters V, Johnson F, Irving L. Heat regulation in some arctic and tropical mammals and birds. Biol Bull. 1950;99(2):237-58. https://doi.org/10.2307/1538741.

46. Whittle AJ, Carobbio S, Martins L, Slawik M, Hondares E, Vazquez MJ, et al. BMP8B increases brown adipose tissue thermogenesis through both central and peripheral actions. Cell. 2012;149(4):871-85. https://doi.org/10.1016/j. cell.2012.02.066.

47. Murano I, Barbatelli G, Giordano A, Cinti S. Noradrenergic parenchymal nerve fiber branching after cold acclimatisation correlates with brown adipocyte density in mouse adipose organ. J Anat. 2009;214(1):171-8. https://doi.org/10.1111/j.1469-7580.2008.01001.x.

48. Kim H, Pennisi PA, Gavrilova O, Pack S, Jou W, Setser-Portas J, East-Palmer J, Tang Y, Manganiello VC, LeRoith D. Effect of adipocyte beta3-adrenergic receptor activation on the type 2 diabetic MKR mice. Am J Physiol Endocrinol Metab. 2006;290(6):E1227-36. https://doi.org/10.1152/ajpendo. 00344.2005.

49. Himms-Hagen J, Cui J, Danforth E Jr, Taatjes DJ, Lang SS, Waters BL, et al. Effect of $\mathrm{CL}-316,243$, a thermogenic beta 3-agonist, on energy balance and brown and white adipose tissues in rats. Am J Phys. 1994; 266(4 Pt 2):R1371-82.

50. Shimada K, Ohno Y, Okamatsu-Ogura Y, Suzuki M, Kamikawa A, Terao A, Kimura K. Neuropeptide $Y$ activates phosphorylation of ERK and STAT3 in stromal vascular cells from brown adipose tissue, but fails to affect thermogenic function of brown adipocytes. Peptides. 2012;34(2):336-42. https://doi.org/10.1016/j.peptides.2012.02.012.

51. Prusiner SB, Cannon B, Ching TM, Lindberg O. Oxidative metabolism in cells isolated from brown adipose tissue. 2. Catecholamine regulated respiratory control. Eur J Biochem. 1968;7(1):51-7. https://doi.org/10.1111/j.1432-1033.1 968.tb19572.x

52. Lenders JW, Willemsen JJ, Beissel T, Kloppenborg PW, Thien T, Benraad TJ. Value of the plasma norepinephrine/3,4-dihydroxyphenylglycol ratio for the diagnosis of pheochromocytoma. Am J Med. 1992;92(2):147-52. https://doi. org/10.1016/0002-9343(92)90105-K.

53. De Matteis R, Ricquier D, Cinti S. TH-, NPY-, SP-, and CGRP-immunoreactive nerves in interscapular brown adipose tissue of adult rats acclimated at different temperatures: an immunohistochemical study. J Neurocytol. 1998; 27(12):877-86. https://doi.org/10.1023/A:1006996922657.

54. Cannon B, Nedergaard J, Lundberg JM, Hökfelt T, Terenius L, Goldstein M. 'Neuropeptide tyrosine' (NPY) is co-stored with noradrenaline in vascular but not in parenchymal sympathetic nerves of brown adipose tissue. Exp Cell Res. 1986;164(2):546-50. https://doi.org/10.1016/0014-4827(86)90052-2.

55. Ivanov A, Purves D. Ongoing electrical activity of superior cervical ganglion cells in mammals of different size. J Comp Neurol. 1989;284(3):398-404. https://doi.org/10.1002/cne.902840307.

56. Purves D. Functional and structural changes in mammalian sympathetic neurones following interruption of their axons. J Physiol. 1975;252(2):429-63. https://doi.org/10.1113/jphysiol.1975.sp011151.

57. De Castro F, Sanchez-Vives MV, Munoz-Martinez EJ, Gallego R. Effects of postganglionic nerve section on synaptic transmission in the superior cervical ganglion of the Guinea-piq. Neuroscience. 1995;67(3):689-95. https://doi.org/10.1016/0306-4522(95)00079-X.

58. Parker MJ, Zhao S, Bredt DS, Sanes JR, Feng G. PSD93 regulates synaptic stability at neuronal cholinergic synapses. J Neurosci. 2004;24(2):378-88. https://doi.org/10.1523/JNEUROSCl.3865-03.2004.
59. Takao-Rikitsu E, Mochida S, Inoue E, Deguchi-Tawarada M, Inoue M, Ohtsuka T, Takai Y. Physical and functional interaction of the active zone proteins, CAST, RIM1, and bassoon, in neurotransmitter release. J Cell Biol. 2004; 164(2):301-11. https://doi.org/10.1083/jcb.200307101.

60. Mermer S, Yalcin M, Turgut $C$. The uptake modeling of DDT and its degradation products (o,p'-DDE and p,p'-DDE) from soil. Sn Appl Sci. 2020;2(4).

61. Ricking $M$, Schwarzbauer J. DDT isomers and metabolites in the environment: an overview. Environ Chem Lett. 2012;10(4):317-23. https:// doi.org/10.1007/s10311-012-0358-2.

62. Ishikawa T, Graham JL, Stanhope KL, Havel PJ, La Merrill MA. Effect of DDT exposure on lipids and energy balance in obese Sprague-Dawley rats before and after weight loss. Toxicol Rep. 2015;2:990-5. https://doi.org/10.1 016/j.toxrep.2015.07.005.

63. Astrup A, Andersen T, Henriksen O, Christensen NJ, Bulow J, Madsen J, et al. Impaired glucose-induced thermogenesis in skeletal muscle in obesity. The role of the sympathoadrenal system. Int J Obes. 1987;11(1):51-66.

64. Bachman ES, Dhillon H, Zhang CY, Cinti S, Bianco AC, Kobilka BK, Lowell BB. betaAR signaling required for diet-induced thermogenesis and obesity resistance. Science. 2002;297(5582):843-5. https://doi.org/10.1126/science.1073160.

65. Mattsson CL, Csikasz Rl, Chernogubova E, Yamamoto DL, Hogberg HT, Amri EZ, Hutchinson DS, Bengtsson T. Beta(1)-adrenergic receptors increase UCP1 in human MADS brown adipocytes and rescue cold-acclimated beta(3)adrenergic receptor-knockout mice via nonshivering thermogenesis. Am J Physiol Endocrinol Metab. 2011;301(6):E1108-18. https://doi.org/10.1152/a jpendo.00085.2011.

66. Uldry M, Yang W, St-Pierre J, Lin J, Seale P, Spiegelman BM. Complementary action of the PGC-1 coactivators in mitochondrial biogenesis and brown fat differentiation. Cell Metab. 2006;3(5):333-41. https://doi.org/10.1016/j.cmet.2 006.04.002.

67. Lyons CE, Razzoli M, Larson E, Svedberg D, Frontini A, Cinti S, Vulchanova L, Sanders M, Thomas M, Bartolomucci A. Optogenetic-induced sympathetic neuromodulation of brown adipose tissue thermogenesis. FASEB J. 2020; 34(2):2765-73. https://doi.org/10.1096/fj.201901361RR.

68. Glebova NO Ginty DD. Growth and survival signals controlling sympathetic nervous system development. Annu Rev Neurosci. 2005;28(1):191-222. https://doi.org/10.1146/annurev.neuro. 28.061604.135659.

69. Purves D, Lichtman JW. Geometrical differences among homologous neurons in mammals. Science. 1985;228(4697):298-302. https://doi.org/1 $0.1126 /$ science.3983631.

70. Chandrasekaran V, Lein PJ. Regulation of dendritogenesis in sympathetic neurons. In: Svorc P, editor. Autonomic nervous system. Croatia: InTechOpen; 2018. p. 91-112. https://doi.org/10.5772/intechopen.80480.

71. Rajapakse N, Ong D, Kortenkamp A. Defining the impact of weakly estrogenic chemicals on the action of steroidal estrogens. Toxicol Sci. 2001; 60(2):296-304. https://doi.org/10.1093/toxsci/60.2.296.

72. Welch RM, Levin W, Conney AH. Estrogenic action of DDT and its analogs. Toxicol Appl Pharmacol. 1969;14(2):358-67. https://doi.org/10.1016/0041008X(69)90117-3.

73. Thomas $\mathrm{P}$, Dong J. Binding and activation of the seven-transmembrane estrogen receptor GPR30 by environmental estrogens: a potential novel mechanism of endocrine disruption. J Steroid Biochem Mol Biol. 2006; 102(1-5):175-9. https://doi.org/10.1016/j.jsbmb.2006.09.017.

74. Kelce WR, Stone CR, Laws SC, Gray LE, Kemppainen JA, Wilson EM. Persistent DDT metabolite $\mathrm{p}, \mathrm{p}^{\prime}-\mathrm{DDE}$ is a potent androgen receptor antagonist. Nature. 1995;375(6532):581-5. https://doi.org/10.1038/375581a0.

75. Sohoni P, Sumpter JP. Several environmental oestrogens are also antiandrogens. J Endocrinol. 1998;158(3):327-39. https://doi.org/10.1677/joe. 0.1580327.

76. Mills $\sqcup$, Gutjahr-Gobell RE, Haebler RA, Horowitz DJ, Jayaraman S, Pruell RJ, et al. Effects of estrogenic (o,p'-DDT; octylphenol) and anti-androgenic ( $\mathrm{p}, \mathrm{p}^{\prime}$ DDE) chemicals on indicators of endocrine status in juvenile male summer flounder (Paralichthys dentatus). Aquat Toxicol 2001;52(2):157-176, Effects of estrogenic (o, $p^{\prime}-D D T$; octylphenol) and anti-androgenic (p,p'-DDE) chemicals on indicators of endocrine status in juvenile male summer flounder (Paralichthys dentatus), DOl: https://doi.org/10.1016/50166-445X(00)00139-9.

77. Nohara K, Waraich RS, Liu S, Ferron M, Waget A, Meyers MS, Karsenty G, Burcelin R, Mauvais-Jarvis F. Developmental androgen excess programs sympathetic tone and adipose tissue dysfunction and predisposes to a cardiometabolic syndrome in female mice. Am J Physiol Endocrinol Metab. 2013;304(12):E1321-30. https://doi.org/10.1152/ajpendo.00620.2012. 
78. Hart EC, Charkoudian N, Miller VM. Sex, hormones and neuroeffector mechanisms. Acta Physiol (Oxf). 2011;203(1):155-65. https://doi.org/10.1111/ j.1748-1716.2010.02192.x.

79. Wyss JM, Carlson SH. Effects of hormone replacement therapy on the sympathetic nervous system and blood pressure. Curr Hypertens Rep. 2003; 5(3):241-6. https://doi.org/10.1007/s11906-003-0027-8.

80. Saleh TM, Connell BJ. Role of oestrogen in the central regulation of autonomic function. Clin Exp Pharmacol Physiol. 2007;34(9):827-32. https:// doi.org/10.1111/j.1440-1681.2007.04663.X.

81. Kaur G, Janik J, Isaacson LG, Callahan P. Estrogen regulation of neurotrophin expression in sympathetic neurons and vascular targets. Brain Res. 2007; 1139:6-14. https://doi.org/10.1016/j.brainres.2006.12.084.

82. Francois $M$, Torres $H$, Huesing C, Zhang R, Saurage C, Lee N, et al. Sympathetic innervation of the interscapular brown adipose tissue in mouse. Ann N Y Acad Sci. 2019;1454(1):3-13. https://doi.org/10.1111/nyas.14119.

83. Young JB, Morrison SF. Effects of fetal and neonatal environment on sympathetic nervous system development. Diabetes Care. 1998;21(Suppl 2): B156-60.

84. Villarroya F, Vidal-Puig A. Beyond the sympathetic tone: the new brown fat activators. Cell Metab. 2013;17(5):638-43. https://doi.org/10.1016/j.cmet.2013. 02.020 .

85. Nguyen KD, Qiu Y, Cui X, Goh YP, Mwangi J, David T, et al. Alternatively activated macrophages produce catecholamines to sustain adaptive thermogenesis. Nature. 2011:480(7375):104-8. https://doi.org/10.1038/nature10653.

86. Ivanov AY. Ongoing Activity in Identified Neurons of the Rat Superior Cervical-Ganglion before and after Partial Denervation of the Submandibular-Gland. Neurophysiology+. 1989;21(6):591-6.

87. Morrison SF, Ramamurthy S, Young JB. Reduced rearing temperature augments responses in sympathetic outflow to brown adipose tissue. J Neurosci. 2000 20(24):9264-71. https://doi.org/10.1523/JNEUROSCI.20-24-09264.2000.

88. Pellegrinelli V, Peirce VJ, Howard L, Virtue S, Turei D, Senzacqua M, et al. Adipocyte-secreted BMP8b mediates adrenergic-induced remodeling of the neuro-vascular network in adipose tissue. Nat Commun. 2018;9(1):4974. https://doi.org/10.1038/s41467-018-07453-x.

89. Ritter R, Scheringer M, MacLeod M, Schenker U, Hungerbuhler K. A multiindividual pharmacokinetic model framework for interpreting time trends of persistent chemicals in human populations: application to a postban situation. Environ Health Perspect. 2009;117(8):1280-6. https://doi.org/10.12 89/ehp.0900648.

90. Valvi D, Walker DI, Inge T, Bartell SM, Jenkins T, Helmrath $M$, et al. Environmental chemical burden in metabolic tissues and systemic biological pathways in bariatric surgery patients: An untargeted metabolomic approach. Environment International. under review.

91. Kanja LW, Skaare JU, Ojwang SB, Maitai CK. A comparison of organochlorine pesticide residues in maternal adipose tissue, maternal blood, cord blood, and human milk from mother/infant pairs. Arch Environ Contam Toxicol. 1992;22(1):21-4. https://doi.org/10.1007/BF00213297.

92. Lin YJ. Metabolic syndrome in children and adolescents born premature and small-for-gestational age: a scenario of developmental origins of health and disease (DOHaD). Pediatr Neonatol. 2018;59(2):109-10. https://doi.org/1 0.1016/j.pedneo.2018.02.009.

93. Young JB. Developmental origins of obesity: a sympathoadrenal perspective. Int J Obes. 2006;30(Suppl 4):S41-9. https://doi.org/10.1038/sj.ijo. 0803518.

94. Young JB. Developmental plasticity in sympathetic nervous system response to fasting in adipose tissues of male rats. Metabolism. 2003:52(12):1621-6. https://doi.org/10.1016/S0026-0495(03)00331-7.

95. Bianco-Miotto T, Craig JM, Gasser YP, van Dijk SJ, Ozanne SE. Epigenetics and DOHaD: from basics to birth and beyond. J Dev Orig Health Dis. 2017 8(5):513-9. https://doi.org/10.1017/S2040174417000733.

96. Kubota T, Miyake K, Hariya N, Mochizuki K. Understanding the epigenetics of neurodevelopmental disorders and DOHaD. J Dev Orig Health Dis. 2015; 6(2):96-104. https://doi.org/10.1017/S2040174415000057.

97. Wadhwa PD, Buss C, Entringer S, Swanson JM. Developmental origins of health and disease: brief history of the approach and current focus on epigenetic mechanisms. Semin Reprod Med. 2009;27(5):358-68. https://doi. org/10.1055/s-0029-1237424

\section{Publisher's Note}

Springer Nature remains neutral with regard to jurisdictional claims in published maps and institutional affiliations.

Ready to submit your research? Choose BMC and benefit from:

- fast, convenient online submission

- thorough peer review by experienced researchers in your field

- rapid publication on acceptance

- support for research data, including large and complex data types

- gold Open Access which fosters wider collaboration and increased citations

- maximum visibility for your research: over $100 \mathrm{M}$ website views per year

At BMC, research is always in progress.

Learn more biomedcentral.com/submissions 